\title{
Studies Toward the Synthesis of Caramboxin Analogues
}

\author{
Ronaldo E. Oliveira Filho, ${ }^{\circledR a}$ Vanessa M. Higa ${ }^{\circledR a}$ and Álvaro T. Omori ${ }^{\circledR *, a}$ \\ ${ }^{a}$ Centro de Ciências Naturais e Humanas, Universidade Federal do ABC, 09210-580 Santo André-SP, Brazil
}

\begin{abstract}
Intrigued by the recent discovery of caramboxin by Brazilian researchers, we present the results from our studies toward the racemic synthesis of caramboxin analogs through the orthocarboxylation of 3,5-dimethoxy benzyl derivatives. Three different approaches were tested, and the route involving a Vilsmeier-Haack formylation followed by a Lindgren oxidation provide a potential intermediate for the synthesis of several caramboxin analogs.
\end{abstract}

Keywords: caramboxin, star fruit, Vilsmeier-Haack reaction, Lindgren oxidation, Curtius rearrangement, Bischler-Napieralski reaction

\section{Introduction}

Originally from Asia, star fruit or carambola (Averrhoa carambola) is a star-shaped fruit popularly consumed and used as traditional medicine in tropical countries around the globe. The toxic effect of this fruit, which mechanism was unclear, involves not only neurotoxicity, but also nephrotoxicity even for people with normal renal function. ${ }^{1}$ Recently, a review of publications from 2000 to 2014 related to the toxicity of carambola noted 27 deaths from 110 patients. In addition, the most commonly reported symptoms after consuming carambola are hiccups, vomiting and confusion. ${ }^{2}$ Although several studies have suggested that oxalate $\left(\mathrm{C}_{2} \mathrm{O}_{4}{ }^{2-}\right)$ is the responsible for toxicity, in 2013, Brazilian researchers ${ }^{3}$ isolated a neurotoxin, caramboxin (1) (Figure 1), that can inhibit the GABAergic system (related to the central nervous system).

Compound 1 contains a phenylalanine skeleton, and the absolute configuration of the carbon $\alpha$ to the amino acid has only been inferred by comparison with the $[\alpha]_{D}$ signal of L-phenylalanine. ${ }^{3}$ So far, only the 2D chemical structure<smiles>COc1cc(O)c(C(=O)O)c(C[C@H](N)C(=O)O)c1</smiles>

caramboxin (1)<smiles>COc1cc(O)c2c(c1)C[C@H](C(=O)O)NC2=O</smiles>

2
Figure 1. Caramboxin structure (1) and the tetrahydroisoquinolinic derivative $\mathbf{2}$ synthesized by Quintiliano and Silva. ${ }^{4}$

*e-mail: alvaro.omori@ufabc.edu.br of $\mathbf{1}$ was confirmed by a computational study using DFT (density functional theory) calculations. ${ }^{5}$ In this case, the theoretical nuclear magnetic resonance (NMR) chemical shifts are in accordance with the experimental NMR measured in dimethyl sulfoxide (DMSO- $d_{6}$ ).

To the best of our knowledge, there are no reports dedicated to the total synthesis of $\mathbf{1}$. In 2012, Quintiliano and Silva ${ }^{4}$ reported a 10-step synthesis of the tetrahydroisoquinolinic derivative $\mathbf{2}$ starting from dimedone (Figure 1). Years later, an unsuccessful attempt to convert 2 to $\mathbf{1}$ was only reported in the $\mathrm{PhD}$ thesis of the same author. ${ }^{6}$

In view of the recent and the important discovery of caramboxin, studies toward the synthesis of derivatives of $\mathbf{1}$ could also be of great importance. The development of synthetic routes to obtain the core of caramboxin could contribute to a possible total synthesis of $\mathbf{1}$.

Structural analysis of $\mathbf{1}$ reveals an intriguing carboxyl group at the ortho position of the phenylalanine moiety, which we consider a significant synthetic challenge. Although a synthesis of (DL)-o-carboxy ${ }^{13} \mathrm{C}$-phenylalanine starting from $o$-bromotoluene was reported, ${ }^{7}$ the required benzylic bromination of toluene could be difficult if an activated aromatic analog is applied. Thus, we investigated three synthetic pathways for the direct $o$-carboxylation of the aromatic ring to synthesize 3-methoxylated lactam 4 (Scheme 1). Hydrolysis of 4 could lead to the 3-methoxylated derivative of caramboxin (3).

The first pathway involves the Bischler-Napieralski (BN) cyclization of $N$-Boc-protected ester $\mathbf{7}$ (Scheme 1, route A). Kim and co-workers ${ }^{8}$ developed an in situ Friedel-Craftstype intramolecular cyclization of $\mathrm{N}$-Boc carbamates via isocyanate intermediate $\mathbf{5}$ using triflic anhydride $\left(\mathrm{Tf}_{2} \mathrm{O}\right)$ and 
<smiles>CCOC(=O)C(Cc1cc(OC)cc(OC)c1)NC(=O)OC</smiles>

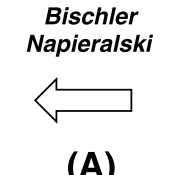

(A)<smiles>CCOC(=O)C(Cc1cc(OC)cc(OC)c1)N=O</smiles>

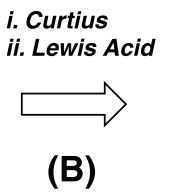

(B)<smiles>CCOC(=O)C(Cc1cc(OC)cc(OC)c1)C(=O)O</smiles><smiles>COc1cc(CO)cc(OC)c1</smiles>

(C)

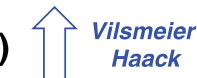<smiles>COc1cc(CCl)c(C=O)c(OC)c1</smiles>

Scheme 1. Three approaches (A, B, and C) explored in this work to prepare lactam 4.

4-(dimethylamino)pyridine (DMAP). In this case, however, $\mathrm{N}$-Boc carbamates containing an $\alpha$-ester group (compound $\mathbf{6}$ ) were not tested. Isocyanate intermediate $\mathbf{5}$ could also be generated in situ through a Curtius rearrangement of monohydrolyzed malonate 7 (Scheme 1, route B). This second pathway arose from the work reported by Judd et al. ${ }^{9}$ These authors reported a one-pot procedure to obtain dihydroisoquinolin-1-ones from activated dihydrocinnamic acids through a modified Curtius rearrangement in the presence of $\mathrm{BF}_{3} \cdot \mathrm{OEt}_{2}$. However, although a protocol to transform monoester malonic acids into $N$-Boc carbamates has been reported, ${ }^{10}$ the direct conversion of compound 7 into isocyanate $\mathbf{5}$ in the presence of a monoester is still unknown.

Finally, the third route was proposed to prioritize the $\mathrm{C}-\mathrm{H}$ functionalization step (Scheme 1, route $\mathrm{C}$ ). Compound $\mathbf{4}$ could be obtained through an intramolecular alkylation of $\mathrm{N}$-amide malonate diester $\mathbf{8}$ followed by a decarboxylation step. Selective oxidation of aldehyde $\mathbf{9}$ could lead to the acid precursor of amide $\mathbf{8}$. Interestingly, compound 9 had previously been synthesized by Danishefsky and co-workers ${ }^{11}$ through the Vilsmeier-Haack formylation of $\mathbf{1 0}$.

\section{Results and Discussion}

Bischler-Napieralski pathway

The Bischler-Napieralski approach had begun with commercially available 3,5-dimethoxybenzoic acid $\mathbf{1 1}$
(Scheme 2). Reduction of $\mathbf{1 1}$ with $\mathrm{LiAlH}_{4}$, followed by benzylic bromination assisted by $\mathrm{PBr}_{3}$ in dioxane provided bromide $\mathbf{1 2}$ in almost quantitative yield over two steps. ${ }^{12} \mathrm{To}$ insert the stable enolate fragment, nucleophilic substitution of $\mathbf{1 2}$ with the carbanion formed from previously prepared $\mathrm{N}$-Boc malonate 14 with $\mathrm{Cs}_{2} \mathrm{CO}_{3}$ gave desired alkylated product $\mathbf{1 5}$ in $80 \%$ isolated yield. Another alkylation protocol using microwave irradiation at high temperature was applied; ${ }^{13}$ however, in this case, we observed that the Boc group from 14 is heat sensitive, and a decrease in the isolated yield was observed.

With carbamate $\mathbf{1 5}$ in hand, two sets of cyclization conditions using $\mathrm{Tf}_{2} \mathrm{O}$ in 2-chloropyridine (2-ClPy) or DMAP, according to Banwell's protocol, were tested. ${ }^{14}$ Even in the presence of the two methoxy groups, in both cases, NMR analysis showed no evidence of cyclization product in the aromatic region. The major product obtained in both cases was the free amine $\mathbf{1 6}$ with 85 and $40 \%$ yield using DMAP and 2-ClPy, respectively. Spyropoulos and Kokotos ${ }^{15}$ proposed the formation of an imino triflate intermediate when $\mathrm{Tf}_{2} \mathrm{O}$ and $\mathrm{N}$-Boc protected amino acids are mixed. We believe the formation of $\mathbf{1 6}$ might have occurred probably by the formation of the isocyanate followed by hydrolysis or by simple deprotection of the Boc through traces of trifluoromethanesulfonic acid. ${ }^{16}$

Although the cyclization of $N$-Boc amides with $\operatorname{Tf}_{2} \mathrm{O}$ has been reported, ${ }^{17}$ no examples containing diesters groups was found. Identical conditions with hydrocinnamic acid derivatives afforded the desired lactam. However, no reports 


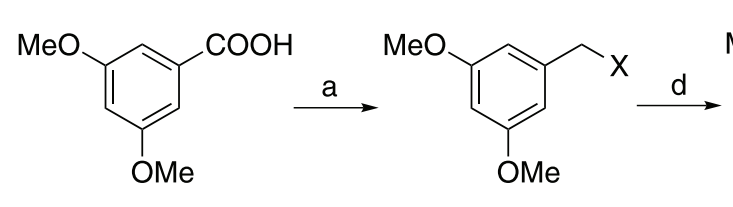

11

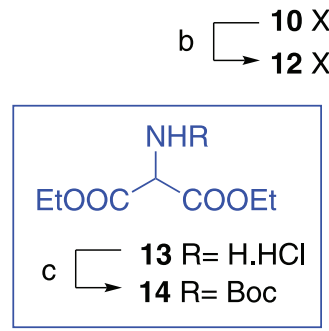

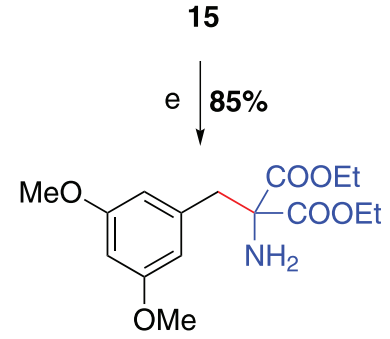

16<smiles>CCOC(=O)NC(Cc1cc(OC)cc(OC)c1)(C(=O)OCC)C(=O)OCC</smiles>

17 $20 \%$<smiles>CCOC(=O)C1(C(=O)OCC)Cc2cc(OC)cc(OC)c2C(C)=N1</smiles>

18

Scheme 2. (a) $\mathrm{LiAlH}_{4}$, THF, $0{ }^{\circ} \mathrm{C} \rightarrow \mathrm{rt}, \mathrm{N}_{2}, 1 \mathrm{~h}$ (99\%); (b) $\mathrm{PBr}_{3}$, dioxane, $40{ }^{\circ} \mathrm{C}, \mathrm{N}_{2}, 1 \mathrm{~h}\left(97 \%\right.$ ); (c) $\mathrm{Boc}_{2} \mathrm{O}, \mathrm{NaHCO}_{3}$, DMAP (cat.), dioxane/ $\mathrm{H}_{2} \mathrm{O}(2: 1)$, rt, overnight (quantitative); (d) 14, $\mathrm{Cs}_{2} \mathrm{CO}_{3}, \mathrm{CH}_{3} \mathrm{CN}$, rt, $\mathrm{N}_{2}, 24 \mathrm{~h}(80 \%)$; (e) $\mathrm{Tf}_{2} \mathrm{O}, 2$-ClPy or DMAP, DCM, $\mathrm{N}_{2}, 0^{\circ} \mathrm{C} \rightarrow \mathrm{rt}$, overnight.

using malonic acid monoesters were found. ${ }^{18}$

In order to verify the influence of the Boc group, the same reaction was conducted using an NHAc group (17). In this case, the desired BN product (18) was obtained in $20 \%$ isolated yield. Thus, probably the lability of the Boc group and the purity of the triflic anhydride are compromising the success of the cyclization.

\section{Curtius rearrangement pathway}

Since the BN pathway did not provide the desired cyclized product, we focused our efforts on the Curtius approach (Scheme 3). Thus, starting with the same bromide, 12, the alkylation with diethyl malonate under microwave irradiation ${ }^{13}$ followed by monohydrolysis with an equimolar amount of $\mathrm{KOH}$ provided monoester acid 7 in good overall yield. Deprotonation of the diethyl malonate with $\mathrm{NaH}$ gave the same diester 19, in only $48 \%$ isolated yield.
Different bases for the Curtius rearrangement using diphenylphosphoryl azide (DPPA) with compound 7 were tested. ${ }^{9}$ Among them, only triethylamine (TEA) provided corresponding isocyanate $\mathbf{5}$ in 59\% isolated yield. However, the intramolecular $\mathrm{S}_{\mathrm{E}} \mathrm{Ar}$ was not observed. Another attempt using a greater amount of $\mathrm{BF}_{3}$ at higher temperature $\left(90^{\circ} \mathrm{C}\right)$ only afforded a trace amount of recovered $\mathbf{5}$. Analogous to the $\mathrm{BN}$ approach, the failure of the reaction can be attributed to the presence of the ester.

\section{Vilsmeier-Haack pathway}

In view of the difficulty of the ortho-carboxylation of functionalized aromatics, likely due to chemoselectivity issues, we decided to prioritize the formylation in the beginning of the route through the Vilsmeier-Haack (VH) reaction of a single substrate. According to the literature, the $\mathrm{VH}$ reaction of benzylic alcohol $\mathbf{1 0}$ was achieved

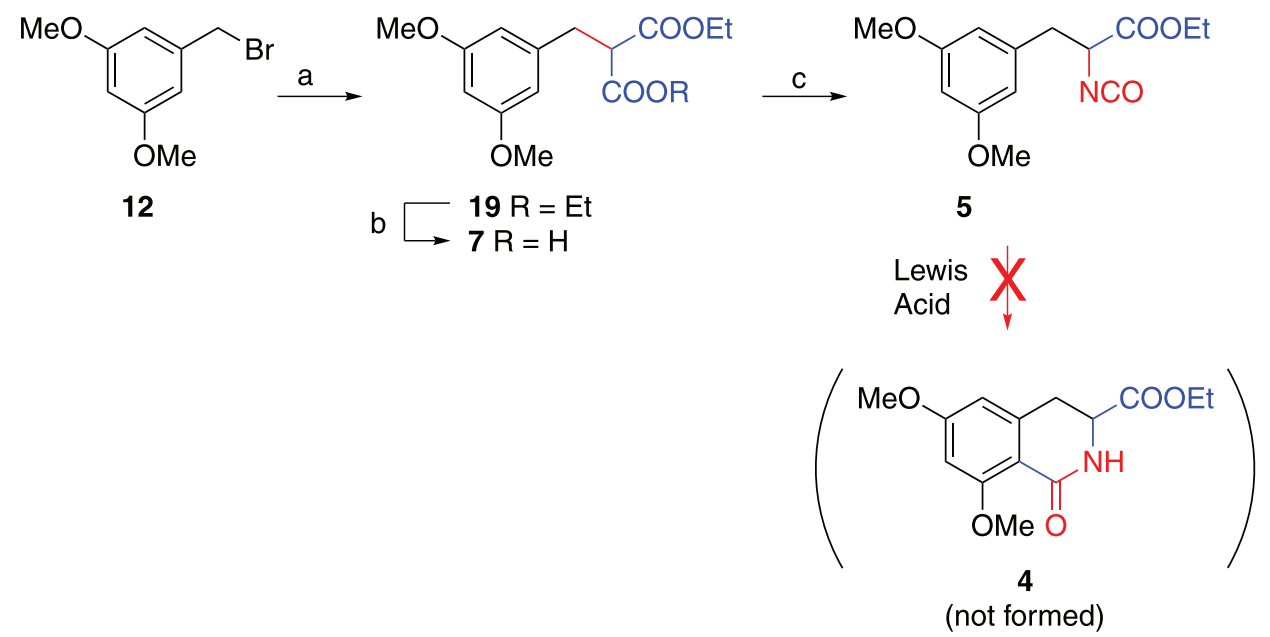

Scheme 3. (a) Diethyl malonate, $\mathrm{K}_{2} \mathrm{CO}_{3}, \mathrm{MeCN}, \mathrm{MW}, 150 \mathrm{~W}, 130{ }^{\circ} \mathrm{C}, \mathrm{N}_{2}, 3 \times 10 \mathrm{~min}$ (77\%); (b) $\mathrm{KOH}, \mathrm{EtOH}, 30{ }^{\circ} \mathrm{C}, \mathrm{N}_{2}, 30 \mathrm{~min}(67 \%$ ); (c) (i) DPPA, TEA, toluene, reflux, $\mathrm{N}_{2}, 1.5 \mathrm{~h}$; (ii) $\mathrm{BF}_{3} \mathrm{Et}_{2} \mathrm{O}, 0 \rightarrow 50{ }^{\circ} \mathrm{C}, \mathrm{N}_{2}, 5 \mathrm{~h}$; (iii) $2 \mathrm{M} \mathrm{NaOH}, \mathrm{rt}, 1 \mathrm{~h}(59 \%)$. 
by Danishefsky and co-workers. ${ }^{11}$ Following the same protocol, using freshly distilled $\mathrm{POCl}_{3}$, we obtained highly functionalized chloride 9 in $90 \%$ isolated yield (Scheme 4). Due to the presence of the labile benzylic chloride, the oxidation of the benzaldehyde to the corresponding benzoic acid was carefully studied. The oxidation of the aldehyde is crucial for the synthesis of the amide. The results of the tested oxidation protocols are summarized in Table 1.

Depending on the oxidation protocol tested, compounds 20, 21 and $\mathbf{2 2}$ were obtained in different ratio. Initially, the protocols for benzaldehyde oxidation using Oxone ${ }^{19}$ and $\mathrm{H}_{2} \mathrm{O}_{2} / \mathrm{AgNO}_{3}{ }^{20}$ did not provide any polar compounds by thin layer chromatography (TLC) analysis. Additionally, oxidation using $\mathrm{KMnO}_{4}$ revealed only traces of compound $\mathbf{2 0}$ or a 1:1 mixture of $\mathbf{2 0}$ and lactone $\mathbf{2 1}$ (entry 4). ${ }^{21}$

Lindgren oxidation is one of the mildest protocols to oxidize benzaldehydes to the corresponding benzoic acids. ${ }^{22}$ This reaction uses sodium chlorite as the oxidant and is operationally simple. However, due to the formation of hypochlorite in situ, chlorination of the activated aromatic ring can be observed. The results of the Lindgren reaction, shown in Table 1 (entries 5 to 12), suggests that the reaction is dependent on the temperature, the reaction time and the careful addition of the chlorite. Extending the reaction time (entry 9) and adding the sodium chlorite in one portion led exclusively to chlorinated acid 22. Very slow addition of sodium chlorite at low temperature provided mixtures of $\mathbf{2 0}$ and $\mathbf{2 1}$ (entries 5 to 8). Reactions at higher temperatures (entries 11 and 12) gave lactone $\mathbf{2 1},{ }^{23}$ indicating that acid $\mathbf{2 0}$ is quite sensitive. Danishefsky and co-workers ${ }^{11}$ reported a 7:1 ratio of $\mathbf{2 0}$ and $\mathbf{2 2}$, and no formation of lactone $\mathbf{2 1}$ was observed. In our case, a higher proportion of the acid was obtained (19:1); however, the isolated yield was only $16 \%$ (entry 7). Another protocol using acetone as the solvent gave similar results to those achieved in the THF/ $\mathrm{H}_{2} \mathrm{O}$ system (entry 10$) .{ }^{24}$ Even in under buffer conditions (entries 11 and 12), lactone $\mathbf{2 1}$ was also obtained.

In terms of isolated yield, we could not reproduce the Danishefsky protocol. Purification of $\mathbf{2 0}$ in the presence of lactone $\mathbf{2 1}$ by chromatographic methods (silica gel, alumina, preparative TLC, and preparative high performance liquid chromatography (HPLC)) and by other methods (acid-base extraction and recrystallization) failed in our hands. In all purification attempts, we observed the lactonization of $\mathbf{2 0}$.

The position of the chlorine atom on the aromatic ring in $\mathbf{2 2}$ was determined by two-dimensional NMR through analysis of the HMBC (heteronuclear multiple-bond correlation) spectra. Long distance heteronuclear coupling<smiles>COc1cc(CO)cc(OC)c1</smiles>

Scheme 4. (a) $\mathrm{POCl}_{3}$, DMF, $0 \rightarrow 75^{\circ} \mathrm{C}, \mathrm{N}_{2}, 2.5 \mathrm{~h}$ (90\%).

Table 1. Conditions tested for the oxidation of benzaldehyde 9

\begin{tabular}{|c|c|c|c|c|c|c|}
\hline entry & Oxidizing agent & Scavenger & Solvent & Temperature $/{ }^{\circ} \mathrm{C}$ & time / min & 20:21:22 ratio $^{\mathrm{a}}$ \\
\hline 1 & Oxone® & - & DMF & $\mathrm{rt}$ & overnight & - \\
\hline 2 & $\mathrm{H}_{2} \mathrm{O}_{2} / \mathrm{AgNO}_{3}$ & - & $\mathrm{MeCN}$ & 50 & overnight & - \\
\hline 3 & $\mathrm{KMnO}_{4}$ & - & $\mathrm{MeCN} / \mathrm{H}_{2} \mathrm{O}$ & $\mathrm{rt}$ & overnight & traces of $\mathbf{2 0}$ \\
\hline 4 & $\mathrm{KMnO}_{4}$ & - & $\mathrm{MeOH} / \mathrm{H}_{2} \mathrm{O}$ & $\mathrm{rt}$ & overnight & $1: 1: 0$ \\
\hline 5 & $\mathrm{NaClO}_{2}$ & $\mathrm{NH}_{2} \mathrm{SO}_{3} \mathrm{H} / \mathrm{DMSO}$ & $\mathrm{THF} / \mathrm{H}_{2} \mathrm{O}$ & 0 & 20 & $1: 1: 0$ \\
\hline 6 & $\mathrm{NaClO}_{2}$ & $\mathrm{NH}_{2} \mathrm{SO}_{3} \mathrm{H} / \mathrm{DMSO}$ & $\mathrm{THF} / \mathrm{H}_{2} \mathrm{O}$ & 0 & 30 & $1.5: 1: 0$ \\
\hline 7 & $\mathrm{NaClO}_{2}$ & $\mathrm{NH}_{2} \mathrm{SO}_{3} \mathrm{H} / \mathrm{DMSO}$ & $\mathrm{THF} / \mathrm{H}_{2} \mathrm{O}$ & 0 & 50 & $19: 1: 0$ \\
\hline 8 & $\mathrm{NaClO}_{2}$ & $\mathrm{NH}_{2} \mathrm{SO}_{3} \mathrm{H} / \mathrm{DMSO}$ & $\mathrm{THF} / \mathrm{H}_{2} \mathrm{O}$ & -20 & 50 & $4: 1: 0$ \\
\hline 9 & $\mathrm{NaClO}_{2}$ & $\mathrm{NH}_{2} \mathrm{SO}_{3} \mathrm{H} / \mathrm{DMSO}$ & $\mathrm{THF} / \mathrm{H}_{2} \mathrm{O}$ & 0 to $\mathrm{rt}$ & overnight & only 22 \\
\hline 10 & $\mathrm{NaClO}_{2}$ & $\mathrm{NH}_{2} \mathrm{SO}_{3} \mathrm{H} / \mathrm{DMSO}$ & acetone & 0 & 30 & $2.5: 1: 0$ \\
\hline 11 & $\mathrm{NaClO}_{2}$ & resorcinol $/ t-\mathrm{BuOH}$ & THF/phosphate buffer & $\mathrm{rt}$ & 60 & only 21 \\
\hline 12 & $\mathrm{NaClO}_{2}$ & DMSO & phosphate buffer & $\mathrm{rt}$ & 120 & only 21 \\
\hline
\end{tabular}

a Determined by LC-MS. DMSO: dimethyl sulfoxide; DMF: dimethylformamide; THF: tetrahydrofuran; rt: room temperature. 
Table 2. Signals in the 2D NMR HMBC spectrum of acid 22

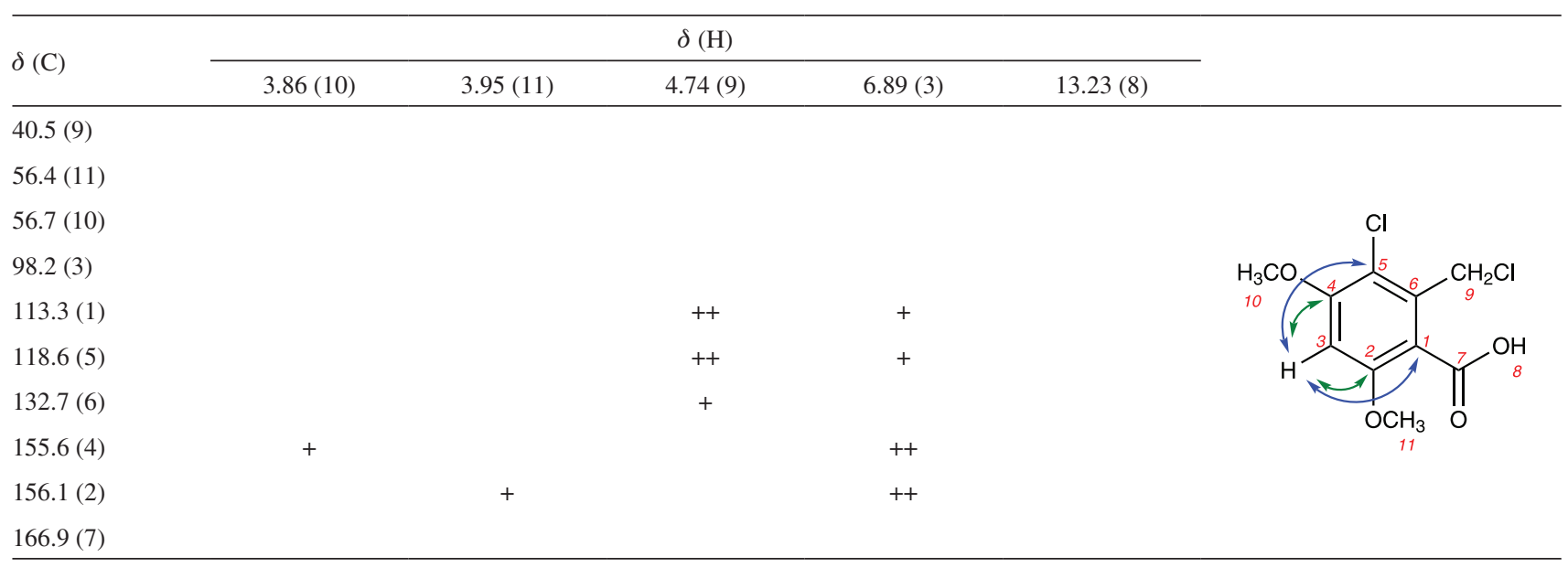

NMR HMBC: nuclear magnetic resonance heteronuclear multiple bond correlation; +: low intensity; ++: high intensity.

constants $\left({ }^{\mathrm{n}} J_{\mathrm{C}-\mathrm{H}}, \mathrm{n} \geq 2\right)^{25}$ of compound 22 are shown in Table 2.

According to Table 2, two-bond correlations between $\mathrm{H}(3) \leftrightarrow \mathrm{C}(4)$ and $\mathrm{H}(3) \leftrightarrow \mathrm{C}(2)$ and less intense three-bond correlations between $\mathrm{H}(3) \leftrightarrow \mathrm{C}(1)$ and $\mathrm{H}(3) \leftrightarrow \mathrm{C}(5)$ were observed. These correlations suggest the aromatic proton is located at $\mathrm{C}(3)$ and the chlorine atom at $\mathrm{C}(5)$ relative to the carboxyl group $(\mathrm{C}(1))$.

Next, the conversion of the acid to the amide was studied (Scheme 5). The diethyl aminomalonate hydrochloride (13) was chosen to guarantee the following intramolecular alkylation step. Thus, impure acid $\mathbf{2 0}$ and dichloride 22 were reacted with HBTU (2-(1H-benzotriazol-1-yl)1,1,3,3-tetramethyluronium hexafluorophosphate) in the presence of triethylamine in dichloromethane (DCM) at room temperature. ${ }^{26}$ Desired amide 8 was obtained in low yield (7\%) and the major compound was lactone $\mathbf{2 1}$, which was obtained in 66\% isolated yield. As expected, 20 was found to be unstable in the presence of triethylamine. However, when dichlorinated acid $\mathbf{2 2}$ was submitted in the same conditions that were used for $\mathbf{2 0}$, we could obtain amide $\mathbf{2 3}$ in $68 \%$ yield. The presence of the chlorine atom on the aromatic ring in $\mathbf{2 3}$ makes the molecule less sensitive to lactonization. Based on the low yields with sensitive acid 20, we decided to continue the pathway using amide $\mathbf{2 3}$ for the next steps.

We considered the intramolecular cyclization of 23 to be the crucial step for this route (Scheme 6). Due to the successful use of $\mathrm{Cs}_{2} \mathrm{CO}_{3}$ in the $\mathrm{BN}$ pathway, we decided to subject dichloride $\mathbf{2 3}$ to similar conditions. A catalytic amount of KI was added to increase the reactivity of the benzylic chloride portion. ${ }^{27}$ In this case, a mixture of lactam $\mathbf{2 4}$ and iodide $\mathbf{2 5}$ were obtained in low yields. However, compound $\mathbf{2 5}$ was recovered and reacted again with $\mathrm{Cs}_{2} \mathrm{CO}_{3}$ to furnish 24. The low yields in the first cyclization protocol can be attributed to the reaction being conducted at room temperature. A better conversion was observed when a higher temperature and microwave (MW) irradiation were used to recycle 25 to $\mathbf{2 4}$. The overall isolated yield of $\mathbf{2 4}$ was $27 \%$ over two steps.<smiles>CCOC(=O)C(NC(=O)c1c(OC)cc(OC)c(Cl)c1CCl)C(=O)NC(C(=O)OCC)C(OCC)Oc1cc(OC)c(C(=O)NC(C(=O)OCC)C(=O)OCC)c(OC)c1</smiles>

Scheme 5. (a) HBTU, TEA, DCM, rt, $\mathrm{N}_{2}, 2.5$ h (7\% for $\mathbf{8}$ and $66 \%$ for $\mathbf{2 1}$ ); (b) HBTU, TEA, DCM, rt, $\mathrm{N}_{2}, 2.5$ h (68\%). 
<smiles>CCOC(=O)C(NC(=O)c1c(OC)cc(OC)c(Cl)c1CCl)C(=O)OCC</smiles>

23<smiles>CCOC(=O)C(NC(=O)c1c(OC)cc(OC)c(Cl)c1CI)C(=O)OCC</smiles>

24
25

b

Scheme 6. (a) $\mathrm{Cs}_{2} \mathrm{CO}_{3}, \mathrm{KI}$ (cat.), DMF, rt, $12 \mathrm{~h}$ (12\% for 24 and $19 \%$ for $\mathbf{2 5}$ ); (b) $\mathrm{Cs}_{2} \mathrm{CO}_{3}, \mathrm{MeCN}, \mathrm{MW}\left(150 \mathrm{~W}, 130{ }^{\circ} \mathrm{C}, 10 \mathrm{~min}\right)(77 \%)$.

Lactam 24 possesses the majority of the functional groups present in caramboxin. Attempts to decarboxylate one of the esters and open the lactam ring in a one-pot fashion were carried out (Scheme 7).$^{28}$ In the presence of $6 \mathrm{~mol} \mathrm{~L}^{-1} \mathrm{HCl}$ at $130^{\circ} \mathrm{C}$, several byproducts were obtained. Liquid chromatography-mass spectrometry (LC-MS) analysis did not provide any evidence of a possible hydrolysis product.<smiles>CCOC(=O)C1(C(=O)OCC)Cc2c(Cl)c(OC)cc(OC)c2C(=O)N1</smiles>

24

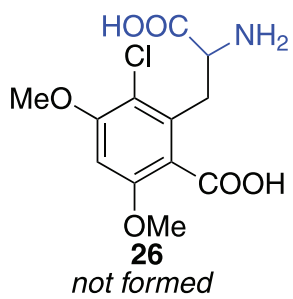

not formed
Scheme 7. (a) $\mathrm{HCl} 6 \mathrm{~mol} \mathrm{~L}^{-1}$, $\mathrm{MW}\left(200 \mathrm{~W}, 130^{\circ} \mathrm{C}\right), 10 \mathrm{~min}$.

The hydrolysis of amides is usually difficult. Thus, to avoid the $\delta$-lactam opening, a portion of remaining acid 22 was esterified by $\mathrm{CH}_{3} \mathrm{I}$ (Scheme 8). Corresponding methyl ester 27 was then submitted to the benzylic alkylation. In this case, we used protected diethyl acetamidomalonate $\mathbf{2 8}$, and corresponding product $\mathbf{2 9}$ was obtained in a higher yield $(60 \%)$ than what was achieved with the intramolecular version (23 to $\mathbf{2 4}$ ). The hydrolysis of amide triester $\mathbf{2 9}$ was partially successful. In fact, the decarboxylation of only one of the malonate esters occurred, affording acetamide benzyl methyl ester 30 in quantitative yield. Unfortunately, further acid hydrolysis of $\mathbf{3 0}$ with longer reaction times and at higher temperatures gave complex mixtures of products.
As previously mentioned, on the basis of the high sensitivity of acid 20, we anticipated that the VilsmeierHaack product, stable aldehyde $\mathbf{9}$, could be converted to a less reactive benzonitrile analogue, which could later be converted to the corresponding acid by hydrolysis. Thus, the treatment of 9 with $\mathrm{NaN}_{3}$ in $\mathrm{POCl}_{3}$ generated nitrile 31 in reasonable yield (67\%) (Scheme 9). ${ }^{29}$ Alkylation of 31 using 28 was accomplished under similar conditions to those mentioned before affording the malonate $\mathbf{3 2}$. At this point, the hydrolysis of the latter compound was more carefully investigated.

Since the last hydrolyses were carried out in acidic media, we decided to test the reactions under basic conditions with two distinct protocols. With the first set of conditions using $2 \mathrm{~mol} \mathrm{~L}^{-1} \mathrm{NaOH}$ and an ultrasonic bath at $80{ }^{\circ} \mathrm{C},{ }^{30}$ we obtained only the corresponding dicarboxylate disodium salt $\mathbf{3 3}$. On the other hand, using $\mathrm{KOH}$ as the base in refluxing ethanol, ${ }^{31}$ we obtained only decarboxylation derivative 34. Interestingly, in the last attempt, when compound $\mathbf{3 3}$ was subjected to acidic hydrolysis $\left(2 \mathrm{~mol} \mathrm{~L}^{-1} \mathrm{HCl}\right)$ for an extended period, we could obtain imino tetrahydroisoquinolinone $\mathbf{3 5}$ in low isolated yield (12\%). In this case, the expected hydrolysis of the acetamido group and the malonate decarboxylation occurred; however, the nitrile group was attacked by the free amino group, and a similar reaction was reported before by Hamley and co-workers. ${ }^{32}$

\section{Conclusions}

We presented three different approaches for the ortho-carboxylation of 3,5-dimethoxy benzyl derivatives
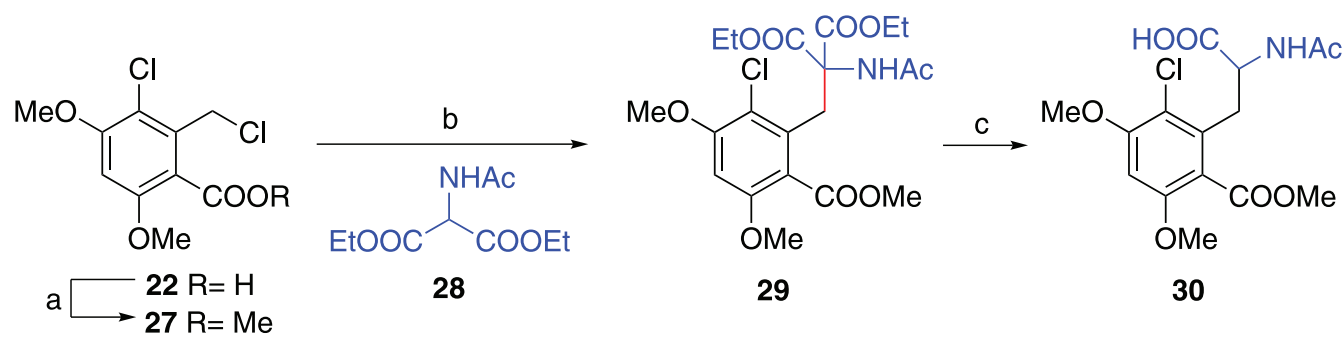

Scheme 8. (a) $\mathrm{CH}_{3} \mathrm{I}, \mathrm{Cs}_{2} \mathrm{CO}_{3}$, DMF, rt, $\mathrm{N}_{2}, 30 \mathrm{~min}$ (59\%); (b) $\mathrm{KI}$ (cat.), $\mathrm{Cs}_{2} \mathrm{CO}_{3}, \mathrm{MeCN}$, rt, overnight (60\%); (c) $\mathrm{HCl} 6 \mathrm{~mol} \mathrm{~L}^{-1}, \mathrm{CH}_{3} \mathrm{COOH}$, MW (150 W, $90{ }^{\circ} \mathrm{C}, 10 \mathrm{~min}$ ) (94\%). 


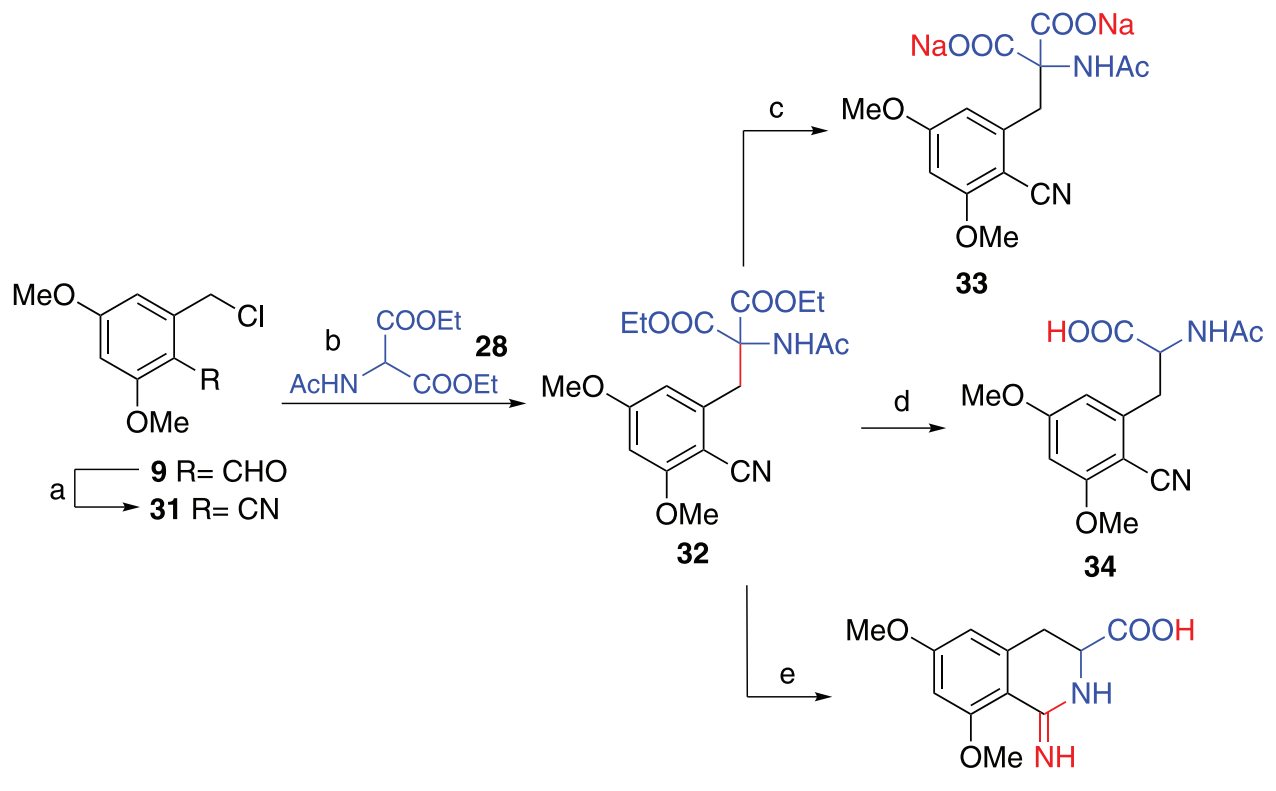

35

Scheme 9. (a) $\mathrm{NaN}_{3}, \mathrm{POCl}_{3}, 50{ }^{\circ} \mathrm{C}, \mathrm{N}_{2}, 1 \mathrm{~h}(67 \%)$; (b) $\mathrm{KI}, \mathrm{Cs}_{2} \mathrm{CO}_{3}, \mathrm{MeCN}, \mathrm{rt}, 48 \mathrm{~h}$ (78\%); (c) $\mathrm{NaOH} 2 \mathrm{~mol} \mathrm{~L}^{-1}$, ultrasonic bath, $80{ }^{\circ} \mathrm{C}, 45 \mathrm{~min}(67 \%)$; (d) $\mathrm{KOH} 35 \%, \mathrm{EtOH}, 80^{\circ} \mathrm{C}, \mathrm{N}_{2}, 2.5 \mathrm{~h}(45 \%)$; (e) $\mathrm{HCl} 2 \mathrm{~mol} \mathrm{~L}^{-1}$, dioxane, reflux, $\mathrm{N}_{2}, 48 \mathrm{~h}(12 \%)$.

toward the preparation of caramboxin analogs. We observed that the insertion of the carboxyl group early on in the synthesis helps avoid chemoselective issues. The Vilsmeier-Haack formylation was chosen due to the concomitant halogenation of the benzylic alcohol, which facilitates the malonate alkylation. For the synthesis of caramboxin, a study regarding the regioselectivity of the $\mathrm{VH}$ will be necessary. We also conclude that the "protection" of the carboxylate by esterification or by functional group interconversion seems to be more attractive than lactamization by an intramolecular alkylation. Lastly, the challenges presented by the final steps, mainly the hydrolysis of the amide and the esters, require more detailed study.

\section{Experimental}

\section{General information}

The reagents (Sigma-Aldrich ${ }^{\circledR}$ ) and solvents (Synth $\left.{ }^{\circledR}\right)$ were used without purification. $\mathrm{POCl}_{3}$ was distillated before used. The TLC analysis was made in silica gel 60 with aluminum, $0.2 \mathrm{~mm}$, with indicator for $254 \mathrm{~nm}$, and compounds visualized using UV irradiation, ninhydrin or vanillin stains. Flash column chromatography was performed using silica gel $60 \AA(35-70 \mu \mathrm{m})$ from Fluka Analytical. The gas chromatography-mass spectrometry (GC-MS) analysis was made in one ion trap, Varian 4000 from Federal University of ABC. The LC-MS analysis was made in quadrupole Agilent 6130 Infinity coupled to an Agilent 1260 HPLC system, from Federal University of
ABC. The HRMS analysis was made in micro-TOF (time of flight) Bruker Daltonics from São Paulo University. The ${ }^{1} \mathrm{H}$ and ${ }^{13} \mathrm{C}$ NMR were made on Varian $(500 \mathrm{MHz})$ from Federal University of ABC and Varian AIII or Bruker DPX300 (300 MHz) from São Paulo University. The solvents used were deuterated chloroform $\left(\mathrm{CDCl}_{3}\right)$ and deuterated dimethyl sulfoxide $\left(\mathrm{DMSO}-d_{6}\right)$. The melting point analyses were made on Büchi B-540 or EZ-Melt SRS-Stanford Research Systems from Federal University of ABC. The purification on HPLC was made in Waters coupling with UV-Vis detector model 2489, using a semipreparative column Phenomenex C18. The Microwave ${ }^{\mathrm{TM}}$ synthesis system were made on CEM Focused, model Discover, from Federal University of ABC.

\section{(3,5-Dimethoxyphenyl)methanol (10, CAS 705-76-0)}<smiles>COc1cc(CO)cc(OC)c1</smiles>

Under $\mathrm{N}_{2}$ atmosphere, a solution of $\mathrm{LiAlH}_{4}(2.1041 \mathrm{~g}, 55.44 \mathrm{mmol})$ in anhydrous THF $(100 \mathrm{~mL})$ was added dropwise to a solution of 3,5-dimethoxybenzoic acid (11) $(10.0 \mathrm{~g}, 54.9 \mathrm{mmol})$ in anhydrous THF $(150 \mathrm{~mL})$ at $0{ }^{\circ} \mathrm{C}$. After stirring for $20 \mathrm{~min}$ at $0{ }^{\circ} \mathrm{C}$ and one hour at room temperature, the reaction was diluted with THF $(90 \mathrm{~mL})$ and water $(4 \mathrm{~mL})$ was added. The mixture was then filtered on celite, washed with ethyl acetate $(4 \times 65 \mathrm{~mL})$ and concentrated under reduced pressure. The resulting clear yellow solid $(9.14 \mathrm{~g}, 54.5 \mathrm{mmol}, 99 \%$ yield) was applied to the next reaction without further purification. $\mathrm{mp}$ 50.2-51.1 ${ }^{\circ} \mathrm{C} ;{ }^{1} \mathrm{H}$ NMR $\left(300 \mathrm{MHz}, \mathrm{CDCl}_{3}\right) \delta 1.90(\mathrm{~s}, 1 \mathrm{H}$, 
$\mathrm{OH}), 3.80\left(\mathrm{~s}, 6 \mathrm{H}, \mathrm{Ar}-\mathrm{OCH}_{3}\right), 4.63\left(\mathrm{~s}, 2 \mathrm{H}, \mathrm{Ar}-\mathrm{CH}_{2}\right), 6.39$ (t, $1 \mathrm{H}, J 2.3 \mathrm{~Hz}, \mathrm{Ar}-H), 6.53$ (d, 2H, J $2.3 \mathrm{~Hz}, \mathrm{Ar}-H) ;{ }^{13} \mathrm{C}$ NMR $\left(126 \mathrm{MHz}, \mathrm{CDCl}_{3}\right) \delta 55.4$ (2C), 65.4, 99.7, 104.6 (2C), 143.4, 161.0 (2C); low resolution (LR)MS (EI (electron ionization)) $m / z \quad 168$ (M+, 100), 151 (12), 139 (45), 109 (15). The spectra of compound $\mathbf{1 0}$ is in accordance with those previously reported. ${ }^{33}$

\section{3,5-Dimethoxybenzyl bromide (12, CAS 877-88-3)}<smiles>COc1cc(CBr)cc(OC)c1</smiles>

Under $\mathrm{N}_{2}$ atmosphere, phosphorus tribromide $(618 \mu \mathrm{L}$, $6.58 \mathrm{mmol}$ ) was added dropwise to a solution containing (3,5-dimethoxyphenyl)methanol (10) $(1.00 \mathrm{~g}, 5.98 \mathrm{mmol})$ in dioxane $(8 \mathrm{~mL})$. The solution was stirred at $40{ }^{\circ} \mathrm{C}$ for $1 \mathrm{~h}$. After cooling to room temperature the reaction was quenched with a saturated $\mathrm{NaHCO}_{3}$ solution $(28 \mathrm{~mL})$ and the resulting aqueous phase was extracted with ethyl acetate $(3 \times 28 \mathrm{~mL})$. The combined organic extracts were dried with $\mathrm{Na}_{2} \mathrm{SO}_{4}$, filtered and concentrated under reduced pressure. The resulting light yellow solid (1.38 g, $5.9 \mathrm{mmol}$, > 99\% yield) was applied to the next reaction without further purification. mp 72.9-73.8 ${ }^{\circ} \mathrm{C} ;{ }^{1} \mathrm{H}$ NMR $\left(500 \mathrm{MHz}, \mathrm{CDCl}_{3}\right) \delta 3.79$ (s, $\left.6 \mathrm{H}, \mathrm{Ar}-\mathrm{OCH}_{3}\right), 4.42\left(\mathrm{~s}, 2 \mathrm{H}, \mathrm{Ar}-\mathrm{CH}_{2}\right), 6.39$ (t, $1 \mathrm{H}, J 2.2 \mathrm{~Hz}$, Ar- $H$ ), 6.54 (d, 2H, J 2.2 Hz, Ar- $H$ ); ${ }^{13} \mathrm{C} \mathrm{NMR} \mathrm{(126} \mathrm{MHz,}$ $\left.\mathrm{CDCl}_{3}\right) \delta 33.6,55.4$ (2C), 100.6, 106.9 (2C), 139.7, 160.9 (2C); LRMS (EI) m/z $232\left(\mathrm{M}^{+}, 30\right), 230$ (27), 152 (15), 151 (100). The spectra of compound 12 is in accordance with those previously reported. ${ }^{34}$

Diethyl 2-((tert-butoxycarbonyl)amino)malonate (14)

EtOoc $\begin{array}{r}\mathrm{NaHCO}_{3}(462 \mathrm{mg}, 5.5 \mathrm{mmol}) \\ \text { was slowly added to a suspension of } \\ \text { diethyl aminomalonate hydrochloride }\end{array}$ (1.0582 $\mathrm{g}, 5 \mathrm{mmol}, \mathbf{1 3})$ in water $(7 \mathrm{~mL})$ and dioxane (10 mL). The resulting solution was stirred for a few minutes at room temperature $(\mathrm{rt})$ until a clear solution appeared. Next, DMAP (6.11 mg, $0.01 \mathrm{mmol}$ ) was added followed by a dropwise addition of a solution of $\mathrm{Boc}_{2} \mathrm{O}$ $(1.2004 \mathrm{~g}, 5.5 \mathrm{mmol})$ in dioxane $(4 \mathrm{~mL})$. The mixture was stirred at room temperature overnight. Then, the solution was concentrated under reduced pressure. The residue was suspended in ethyl acetate $(25 \mathrm{~mL})$ and then extracted with $5 \%$ aqueous $\mathrm{KHSO}_{4}$ solution $(20 \mathrm{~mL})$, saturated aqueous $\mathrm{NaHCO}_{3}$ solution $(20 \mathrm{~mL})$, water $(15 \mathrm{~mL})$ and brine $(15 \mathrm{~mL})$. The organic phase was dried with anhydrous $\mathrm{Na}_{2} \mathrm{SO}_{4}$ and concentrated under reduced pressure. $1.2803 \mathrm{~g}, 4.65 \mathrm{mmol}$ (46\% yield) of a light oil was obtained and applied for the next reaction without further purification. LRMS (ESI (electrospray ionization)) $\mathrm{m} / z$ 276.1 $\left.\left[\mathrm{M}-\mathrm{CO}_{2}\right]^{+}, 100\right)$.

Diethyl 2-((tert-butoxycarbonyl)amino)-2-(3,5-dimethoxybenzyl)malonate (15)<smiles>CCOC(=O)NC(Cc1cc(OC)cc(OC)c1)(C(=O)OCC)C(=O)OCC</smiles>

A solution of bromide 12 (231 mg, $1 \mathrm{mmol}$ ), diethyl (Boc-amino) malonate (275 $\mathrm{mg}$, $1.1 \mathrm{mmol})$ and $\mathrm{Cs}_{2} \mathrm{CO}_{3}$ (325 mg, $1.1 \mathrm{mmol}$ ) in acetonitrile $(4.5 \mathrm{~mL})$ was stirred for $25 \mathrm{~h}$ at room temperature. The reaction was then diluted in $30 \mathrm{~mL}$ of ethyl acetate and extracted with water and brine. The organic phase was dried with anhydrous $\mathrm{Na}_{2} \mathrm{SO}_{4}$ and concentrated under reduced pressure. The residue was purified by flash chromatography on silica gel, using ethyl acetate/hexane (4:1) as the eluent, affording a white solid (326.2 mg, $0.77 \mathrm{mmol}, 77 \%$ yield). mp 69.7-72.5 ${ }^{\circ} \mathrm{C}$; ${ }^{1} \mathrm{H}$ NMR $\left(500 \mathrm{MHz}, \mathrm{CDCl}_{3}\right) \delta 1.29(\mathrm{t}, 6 \mathrm{H}, J 7.1 \mathrm{~Hz}$, $\mathrm{CO}_{2} \mathrm{CH}_{2} \mathrm{CH}_{3}$ ), 1.47 (s, 9H, $\left.t-\mathrm{Bu}\right), 3.55$ (s, 2H, Ar- $\mathrm{CH}_{2} \mathrm{C}$ ), 3.74 (s, 6H, Ar-OCH $), 4.17-4.26\left(\mathrm{~m}, 2 \mathrm{H}, \mathrm{CO}_{2} \mathrm{CH}_{2} \mathrm{CH}_{3}\right.$ ), 4.27-4.36 (m, 2H, $\left.\mathrm{CO}_{2} \mathrm{CH}_{2} \mathrm{CH}_{3}\right), 5.79$ (s, $\left.1 \mathrm{H}, \mathrm{N}-\mathrm{H}\right), 6.20$ (d, $2 \mathrm{H}, J 2.0 \mathrm{~Hz}, \mathrm{Ar}-H), 6.34(\mathrm{t}, 1 \mathrm{H}, J 2.2 \mathrm{~Hz}, \mathrm{Ar}-H) ;{ }^{13} \mathrm{C} \mathrm{NMR}$ $\left(126 \mathrm{MHz} \mathrm{CDCl}_{3}\right) \delta 14.0$ (2C), 28.2 (3C), 38.5, 55.1 (2C), 62.5 (2C), 67.1, 80.1, 99.1, 108.1 (2C), 137.4, 153.8, 160.5 (2C), 167.6 (2C); LRMS (ESI) $m / z 426.2[\mathrm{M}+\mathrm{H}]^{+}$.<smiles>CCOC(=O)C(N)(Cc1cc(OC)cc(OC)c1)C(=O)OCC</smiles>
and DMAP (78.2 $\mathrm{mg}, 0.64 \mathrm{mmol})$ in DCM $(8 \mathrm{~mL})$. The mixture was stirred for $18 \mathrm{~h}$ at $0{ }^{\circ} \mathrm{C}$, in $\mathrm{N}_{2}$. The reaction was then diluted in $5 \mathrm{~mL}$ of DCM and washed with a saturated $\mathrm{Na}_{2} \mathrm{CO}_{3}$ solution $(5 \mathrm{~mL})$, then $20 \%$ citric acid solution $(5 \mathrm{~mL})$ and saturated $\mathrm{Na}_{2} \mathrm{CO}_{3}$ solution $(5 \mathrm{~mL})$. The combined organic phases was dried with anhydrous $\mathrm{Na}_{2} \mathrm{SO}_{4}$ and concentrated under pressure. The residue was purified by flash chromatography, on silica gel, using ethyl acetate/hexane $(2: 1)$ as the eluent; the amine $\mathbf{1 6}$ (58 mg, $0.178 \mathrm{mmol}, 85 \%$ yield) was obtained as a light oil. ${ }^{1} \mathrm{H}$ NMR (500 MHz, $\left.\mathrm{CDCl}_{3}\right) \delta 1.29$ (t, 6H, J 7.1 Hz, $\mathrm{CO}_{2} \mathrm{CH}_{2} \mathrm{CH}_{3}$ ), 2.10 (s, 2H, NH$H_{2}$ ), 3.28 (s, 2H, Ar- $H$ ), 3.75 (s, $6 \mathrm{H}, \mathrm{Ar}-\mathrm{OCH}_{3}$ ), 4.25 (qd, $4 \mathrm{H}, J 7.1,1.8 \mathrm{~Hz}, \mathrm{CO}_{2} \mathrm{CH}_{2} \mathrm{CH}_{3}$ ), 6.33 (d, 2H, J $2.3 \mathrm{~Hz}, \mathrm{Ar}-H), 6.36$ (t, $1 \mathrm{H}, J 2.3 \mathrm{~Hz}, \mathrm{Ar}-H)$; ${ }^{13} \mathrm{C} \mathrm{NMR}\left(126 \mathrm{MHz}, \mathrm{CDCl}_{3}\right) \delta 13.9(2 \mathrm{C}), 41.1,55.2(2 \mathrm{C})$, 62.0 (2C), 66.2, 99.1 (2C), 108.1 (2C), 137.0, 160.7 (2C), 170.8; LRMS (ESI) $m / z 352.1[\mathrm{M}+\mathrm{H}]^{+}$.

Diethyl 2-(3,5-dimethoxybenzyl)malonate (19, CAS 585968-7)

A mixture of bromide 12 (334 $\mathrm{mg}, 1.44 \mathrm{mmol}$ ), 
<smiles>CCOC(=O)C(Cc1cc(OC)cc(OC)c1)C(=O)OCC</smiles>

diethyl manolate $(263 \mu \mathrm{L}$, $1.73 \mathrm{mmol}), \mathrm{Cs}_{2} \mathrm{CO}_{3}$ (562 $\mathrm{mg}, 1.73 \mathrm{mmol}$ ) and $\mathrm{CH}_{3} \mathrm{CN}(13 \mathrm{~mL})$ was added to an Ace sealed tube. Three cycles of irradiation at $150 \mathrm{~W}$, with maximum temperature of $130{ }^{\circ} \mathrm{C}$ for $10 \mathrm{~min}$ were done. Next, the reaction was diluted in ethyl acetate $(35 \mathrm{~mL})$ and washed with water $(20 \mathrm{~mL})$ and brine $(20 \mathrm{~mL})$. The organic phase was dried with anhydrous $\mathrm{Na}_{2} \mathrm{SO}_{4}$ and concentrated under reduced pressure. An oil 19 (344.5 mg, $1.11 \mathrm{mmol}, 77 \%$ yield) was obtained and submitted to the next reaction without further purification. ${ }^{1} \mathrm{H}$ NMR $\left(500 \mathrm{MHz}, \mathrm{CDCl}_{3}\right) \delta 1.23\left(\mathrm{t}, 6 \mathrm{H}, J 7.1 \mathrm{~Hz}, \mathrm{CO}_{2} \mathrm{CH}_{2} \mathrm{CH}_{3}\right)$, 3.16 (d, 2H, J 7.8 Hz, Ar- $\mathrm{CH}_{2} \mathrm{CH}$ ), 3.63 (t, 1H, J 7.8 Hz, Ar- $\mathrm{CH}_{2} \mathrm{CH}$ ), 3.76 (s, 6H, Ar- $\mathrm{OCH}_{3}$ ), 4.18 (dq, 4H, J 10.7, 7.1, 7.1, 3.6, $\left.3.4 \mathrm{~Hz}, \mathrm{CO}_{2} \mathrm{CH}_{2} \mathrm{CH}_{3}\right), 6.32$ (s, $1 \mathrm{H}, J 2.2 \mathrm{~Hz}$, Ar- $H), 6.36(\mathrm{~d}, 2 \mathrm{H}, J 2.2 \mathrm{~Hz}, \mathrm{Ar}-H) ;{ }^{13} \mathrm{C}$ NMR $(126 \mathrm{MHz}$, $\left.\mathrm{CDCl}_{3}\right) \delta 14.0(2 \mathrm{C}), 34.9,53.7,55.3(2 \mathrm{C}), 61.5,98.8,106.8$ (2C), 140.3, 160.8 (2C), 168.9 (2C); LRMS (EI) $\mathrm{m} / z 310$ $\left(\mathrm{M}^{+}, 70\right), 265$ (8), 237 (100), 219 (16), 192 (60), 165 (12), 136 (6), 105 (4), 91 (4). The spectra of compound 19 are in accordance with those previously reported. ${ }^{35}$

\section{2-(3,5-Dimethoxybenzyl)-3-ethoxy-3-oxopropanoic acid (7)}

$\mathrm{MeO}$<smiles>CCOC(=O)C(Cc1cccc(OC)c1)C(=O)O</smiles>

To a solution of malonate 19 (173 mg, $0.56 \mathrm{mmol})$ in ethanol ( $3 \mathrm{~mL})$, a solution of $\mathrm{KOH}(32 \mathrm{mg}, 0.57 \mathrm{mmol})$ in water $(0.65 \mathrm{~mL})$ was slowly added. The reaction was stirred for $30 \mathrm{~min}$ at $30{ }^{\circ} \mathrm{C}$. Then, a $5 \%$ aqueous $\mathrm{HCl}$ solution $(3 \mathrm{~mL})$ was slowly added. The mixture was diluted in water $(5 \mathrm{~mL})$ and extracted with dichloromethane $(3 \times$ $5 \mathrm{~mL}$ ). The organic phases was combined and neutralized with saturated aqueous $\mathrm{NaHCO}_{3}$ solution $(10 \mathrm{~mL})$. The remaining aqueous phase was acidified with $2 \mathrm{M} \mathrm{HCl}$ solution and extracted with more DCM $(3 \times 5 \mathrm{~mL})$. All the organic phases was combined, dried with anhydrous $\mathrm{Na}_{2} \mathrm{SO}_{4}$ and concentrated under reduced pressure, affording white solid (116.8 mg, $0.41 \mathrm{mmol}, 73 \%$ yield). The crude product was applied to the next reaction without further purification. ${ }^{1} \mathrm{H}$ NMR $\left(300 \mathrm{MHz}, \mathrm{CDCl}_{3}\right) \delta 1.23(\mathrm{t}, 3 \mathrm{H}$, $\left.J 7.1 \mathrm{~Hz}, \mathrm{CO}_{2} \mathrm{CH}_{2} \mathrm{CH}_{3}\right), 3.18$ (d, 2H, J 7.7 Hz, Ar-CH $\mathrm{CH}$ ), 3.70 (t, $1 \mathrm{H}, J 7.7 \mathrm{~Hz}, \mathrm{Ar}-\mathrm{CH}_{2} \mathrm{CH}$ ), 3.76 (s, 6H, Ar- $\mathrm{OCH}_{3}$ ), 4.19 (q, 2H, J 7.1 Hz, $\left.\mathrm{CO}_{2} \mathrm{CH}_{2} \mathrm{CH}_{3}\right), 6.34(\mathrm{t}, 1 \mathrm{H}, J 2.2 \mathrm{~Hz}$, Ar-H), 6.37 (d, 2H, J 2.2 Hz, Ar-H), 9.08 (s, 1H, COOH); ${ }^{13} \mathrm{C} \mathrm{NMR}\left(75 \mathrm{MHz}, \mathrm{CDCl}_{3}\right) \delta 13.9,34.8,53.3,55.2(2 \mathrm{C})$, 61.8, 98.9, 106.7 (2C), 139.7, 160.8 (2C), 168.6, 174.0; LRMS (EI) $\left.m / z, 238\left[\mathrm{M}-\mathrm{CO}_{2}\right]^{+}, 85\right), 193$ (20), 165 (100).

Ethyl 3-(3,5-dimethoxyphenyl)-2-isocyanatopropanoate (5) Diphenyl phosphoryl azide ( $86 \mu \mathrm{L}, 0.4 \mathrm{mmol})$ was added<smiles>CCOC(=O)C(Cc1cc(OC)cc(OC)c1)N=O</smiles>

to a solution containing 2-(3,5-dimethoxybenzyl)3-ethoxy-3-oxopropanoic acid (115 mg, $0.4 \mathrm{mmol}, 7)$

and triethylamine $(55 \mu \mathrm{L}, 0.4 \mathrm{mmol})$ in toluene $(4 \mathrm{~mL})$. The mixture was stirred for $90 \mathrm{~min}$ at $90{ }^{\circ} \mathrm{C}$. Then, the reaction was cooled at $0{ }^{\circ} \mathrm{C}$ and $\mathrm{BF}_{3} \cdot \mathrm{OEt}_{2}(200 \mu \mathrm{L})$ was added. After, stirring at $50{ }^{\circ} \mathrm{C}$ for $5 \mathrm{~h}$ in $\mathrm{N}_{2}$, the mixture was cooled at $\mathrm{rt}$ and then a $2 \mathrm{M} \mathrm{NaOH}$ solution was added (at $\mathrm{pH}=10)$. Next, after extraction with EtOAc $(3 \times 10 \mathrm{~mL})$ and brine $(10 \mathrm{~mL})$ the combined organic phases was dried with anhydrous $\mathrm{Na}_{2} \mathrm{SO}_{4}$ and concentrated under pressure. The residue was purified by flash chromatography, on silica gel, using ethyl acetate/hexane (4:1 to 1:1) as the eluent; the isocyanate 5 (20.6 mg, $0.07 \mathrm{mmol}, 19 \%$ yield) was obtained as a light oil. ${ }^{1} \mathrm{H} \mathrm{NMR}\left(300 \mathrm{MHz}, \mathrm{CDCl}_{3}\right) \delta 1.25(\mathrm{t}, 3 \mathrm{H}$, $\mathrm{CO}_{2} \mathrm{CH}_{2} \mathrm{CH}_{3}$ ), 3.02 (d, 2H, J $5.8 \mathrm{~Hz}, \mathrm{Ar}-\mathrm{CH}_{2} \mathrm{CH}$ ), 3.74 (s, 6H, Ar-OCH ${ }_{3}$, 4.13-4.18 (m, 2H, $\left.\mathrm{CO}_{2} \mathrm{CH}_{2} \mathrm{CH}_{3}\right)$, 4.664.77 (m, 1H, Ar- $\left.\mathrm{CH}_{2} \mathrm{CH}\right), 6.27$ (d, 2H, J $2.2 \mathrm{~Hz}, o-\mathrm{Ar}-H$ ), 6.30-6.36 (m, 1H, p-Ar-H); LRMS (EI) $m / z 279\left(\mathrm{M}^{+}, 100\right)$.

2-(Chloromethyl)-4,6-dimethoxybenzaldehyde (9, CAS 166322-67-4)<smiles>COc1cc(CCl)c(C=O)c(OC)c1</smiles>

First, a solution of a freshly distilled $\mathrm{POCl}_{3}(4.44 \mathrm{~mL}, 47.6 \mathrm{mmol})$ in anhydrous DMF $(7.2 \mathrm{~mL})$ at $0{ }^{\circ} \mathrm{C}$ in $\mathrm{N}_{2}$ was prepared. To this solution, a solution of (3,5-dimethoxyphenyl) methanol (10) (2.0 g, $11.9 \mathrm{mmol})$ in anhydrous DMF $(5.1 \mathrm{~mL})$ was slowly added and the resulting mixture was stirred for $2 \mathrm{~h}$ at $75^{\circ} \mathrm{C}$ in $\mathrm{N}_{2}$. The reaction was cooled to room temperature and poured into ice water $(180 \mathrm{~mL})$. The $\mathrm{pH}$ was adjusted to 7 by addition of $2 \mathrm{M} \mathrm{NaOH}$ solution and the mixture was stirred for additional $1.5 \mathrm{~h}$. The green precipitate was filtered, washed with cooled water and was dried under reduced pressure. The solid was diluted in acetone, and the solution was filtered in celite and the filtrate was concentrated under reduced pressure. Finally, the solid was purified by flash chromatography on silica gel, eluting with a gradient of ethyl acetate/hexane (4:1 to $1: 1)$, providing a white solid $(2.286 \mathrm{~g}, 10.7 \mathrm{mmol}, 90 \%$ yield). mp 105.5-106.5 ${ }^{\circ} \mathrm{C} ;{ }^{1} \mathrm{H}$ NMR (300 MHz, $\left.\mathrm{CDCl}_{3}\right) \delta$ 3.90 (s, 6H, Ar-OCH $H_{3}$, 5.05 (s, 2H, Ar- $\left.\mathrm{CH}_{2}\right), 6.44$ (d, 1H, $J 2.4 \mathrm{~Hz}, \operatorname{Ar}-H$ ), 6.76 (d, 1H, J $2.9 \mathrm{~Hz}, \mathrm{Ar}-H$ ), 10.46 (s, $1 \mathrm{H}, \mathrm{Ar}-\mathrm{CHO}) ;{ }^{13} \mathrm{C} \mathrm{NMR}\left(75 \mathrm{MHz}, \mathrm{CDCl}_{3}\right) \delta 44.9,55.7$, 56.0, 97.7, 107.6, 115.9, 142.4, 165.0, 165.3, 189.9; LRMS (ESI) $m / z 215.0\left([\mathrm{M}+\mathrm{H}]^{+}, 100\right), 217.0$; HRMS (TOF) $m / z$, observed: 237.0278; $\mathrm{C}_{10} \mathrm{H}_{11} \mathrm{ClO}_{3} \mathrm{Na}[\mathrm{M}+\mathrm{Na}]^{+}$requires: 237.0294. The spectra of compound $\mathbf{9}$ is in accordance with those previously reported. ${ }^{36}$ 
2-(Chloromethyl)-4,6-dimethoxybenzoic acid (20)<smiles>COc1cc(CCl)c(C(=O)O)c(OC)c1</smiles>

To a solution of 2-(chloromethy 1)-4,6-dimethoxybenzaldehyde 9 (500 mg, $2.33 \mathrm{mmol})$ in acetone $(25 \mathrm{~mL})$ and DMSO $(10 \mathrm{~mL})$ at $0{ }^{\circ} \mathrm{C}$, a solution of sulfamic acid $(384.5 \mathrm{mg}$, $3.96 \mathrm{mmol})$ in water $(7.5 \mathrm{~mL})$ was added. The reaction was stirred for $1 \mathrm{~min}$ on $\mathrm{N}_{2}$ atmosphere. To this solution, a solution of $\mathrm{NClO}_{2}(326.5 \mathrm{mg}, 3.61 \mathrm{mmol})$ in water $(17 \mathrm{~mL})$ was slowly added. After stirring for $30 \mathrm{~min}$ at $0{ }^{\circ} \mathrm{C}$ the reaction was extracted with ethyl acetate $(3 \times 15 \mathrm{~mL})$. The combined organic phases were washed with water $(15 \mathrm{~mL})$ and brine $(15 \mathrm{~mL})$, then dried with anhydrous $\mathrm{Na}_{2} \mathrm{SO}_{4}$ and concentrated under reduced pressure. A yellow solid $(347 \mathrm{mg}$ ) of a mixture of the acid 20 with the lactone 21 (1:1 ratio) was obtained. LRMS (ESI) $m / z 231.0\left([\mathrm{M}+\mathrm{H}]^{+}, 100\right), 233.0$ (34) for acid 20 and $195.1\left(\mathrm{M}^{+}, 100\right)$ for lactone 21.

3-Chloro-2-(chloromethyl)-4,6-dimethoxybenzoic acid (22)<smiles>COc1cc(OC)c(C(=O)O)c(CCl)c1Cl</smiles>

To a solution of 2-(chlorometh y 1) - 4, 6-dimeth ox y benzaldehyde (9) (100 mg, $0.47 \mathrm{mmol})$ in $\mathrm{THF}(5 \mathrm{~mL})$ and DMSO $(0.3 \mathrm{~mL})$ at $0{ }^{\circ} \mathrm{C}$, a solution of sulfamic acid

(153.8 $\mathrm{mg}, 1.58 \mathrm{mmol})$ in water $(2.5 \mathrm{~mL})$ was added. The reaction was stirred for $1 \mathrm{~min}$ on $\mathrm{N}_{2}$ atmosphere. The $\mathrm{NaClO}_{2}(136.0 \mathrm{mg}, 1.50 \mathrm{mmol})$ was fastly added and stirred for $1 \mathrm{~h}$ at $0{ }^{\circ} \mathrm{C}$ and overnight at $\mathrm{rt}$. The reaction was diluted with ethyl acetate $(25 \mathrm{~mL})$ and extracted with saturated aqueous $\mathrm{NH}_{4} \mathrm{Cl}$ solution $(40 \mathrm{~mL})$. The aqueous phase was extracted with more ethyl acetate $(15 \mathrm{~mL})$. The combined organic phases were washed with brine, dried with anhydrous $\mathrm{MgSO}_{4}$ and concentrated under reduced pressure, providing a white solid $(134.0 \mathrm{mg}$, in a quantitative yield). mp $143{ }^{\circ} \mathrm{C} ;{ }^{1} \mathrm{H}$ NMR $(500 \mathrm{MHz}$, DMSO- $\left.d_{6}\right) \delta 3.86\left(\mathrm{~s}, 3 \mathrm{H}, \mathrm{Ar}-\mathrm{OCH}_{3}\right), 3.94$ (s, 3H, Ar-OCH${ }_{3}$ ), 4.74 (s, 2H, Ar- $\mathrm{CH}_{2}$ ), 6.89 (s, 1H, Ar-H), 13.23 (br s, 1H, $\left.\mathrm{Ar}-\mathrm{CO}_{2} H\right) ;{ }^{13} \mathrm{C}$ NMR $\left(126 \mathrm{MHz}, \mathrm{DMSO}-d_{6}\right) \delta 40.5,56.4$, 56.7, 98.2, 109.5, 113.3, 118.6, 132.7, 155.6, 156.2, 166.9; heteronuclear multiple quantum correlation (HMQC,

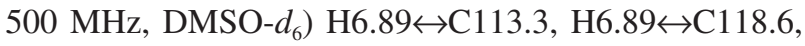

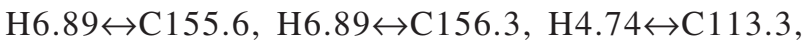
$\mathrm{H} 4.74 \leftrightarrow \mathrm{C} 118.5, \mathrm{H} 4.74 \leftrightarrow \mathrm{C} 132.7, \mathrm{H} 3.95 \leftrightarrow \mathrm{C} 156.1$, H3.86↔C155.7; LRMS (ESI) $m / z 267.0$ (65), 265.0 $\left([\mathrm{M}+\mathrm{H}]^{+}, 100\right), 247.0$ (24), 229.0 (35), 117.1 (20); HRMS (TOF) $m / z$, observed: $286.9845 ; \mathrm{C}_{10} \mathrm{H}_{10} \mathrm{Cl}_{2} \mathrm{O}_{4} \mathrm{Na}[\mathrm{M}+\mathrm{Na}]^{+}$ requires: 286.9853 .
Diethyl 2-(3-chloro-2-(chloromethyl)-4,6-dimethoxybenzamido)malonate (23)<smiles>CCOC(=O)C(NC(=O)c1c(OC)cc(OC)c(Cl)c1CCl)C(=O)OCC</smiles>

To a solution of acid 22 (200 $\mathrm{mg}$, $0.75 \mathrm{mmol})$, trietilamine (420 mL, $2.6 \mathrm{mmol})$ in DCM (10 mL), HBTU (363 mg, $0.96 \mathrm{mmol}$ ) was added. After stirring for $15 \mathrm{~min}$ at room temperature, a solution of diethyl aminomalonate hydrochloride (203 mg, $0.95 \mathrm{mmol})$ in DCM $(10 \mathrm{~mL})$ was added dropwise, and the resulting mixture was stirred for additional $2.5 \mathrm{~h}$ at rt. The reaction was diluted in DCM $(50 \mathrm{~mL})$ and washed with $5 \%$ aqueous citric acid solution, saturated aqueous $\mathrm{NaHCO}_{3}$ solution and water. The organic phase was dried with anhydrous $\mathrm{Na}_{2} \mathrm{SO}_{4}$ and concentrated under reduced pressure. The crude product was purified by two consecutive flash chromatography columns, on silica gel: the first was eluted with ethyl acetate/hexane (1:1) and second was eluted with DCM/hexane (3:1), giving the compound 23 as a white solid (205 mg, $0.47 \mathrm{mmol}, 63 \%$ yield). mp 152-156 ${ }^{\circ} \mathrm{C} ;{ }^{1} \mathrm{H}$ NMR (500 MHz, $\left.\mathrm{CDCl}_{3}\right) \delta 1.33$ (t, 6H, J $4.4 \mathrm{~Hz}, \mathrm{CO}_{2} \mathrm{CH}_{2} \mathrm{CH}_{3}$ ), 3.87 (s, 3H, Ar-OCH $)$, 3.95 (s, 3H, Ar-OCH $), 4.32\left(\mathrm{~m}, 4 \mathrm{H}, \mathrm{CO}_{2} \mathrm{CH}_{2} \mathrm{CH}_{3}\right), 4.87$ (s, 2H, Ar-CH $\mathrm{CH}_{2}, 5.34$ (d, 1H, J $3.8 \mathrm{~Hz},-\mathrm{CH}-\mathrm{NH}-$ ), 6.52 (s, 1H, -CH-NH-), 7.12 (d, $1 \mathrm{H}, J 3.9 \mathrm{~Hz}, \mathrm{Ar}-H) ;{ }^{13} \mathrm{C}$ NMR $\left(126 \mathrm{MHz}, \mathrm{CDCl}_{3}\right) \delta 14.1,40.5,56.4,56.5,57.0,62.8$, 96.7, 115.8, 118.5, 135.5, 156.3, 165.3, 166.0; LRMS (ESI) $m / z, 424.1$ (75), $422.1\left([\mathrm{M}+\mathrm{H}]^{+}, 100\right), 249.0$ (20), 247.0 $\left(\mathrm{M}^{+}-\mathrm{NHCH}\left(\mathrm{CO}_{2} \mathrm{Et}\right)_{2}, 40\right)$; HRMS (TOF) $\mathrm{m} / z$, observed: 246.9920; $\mathrm{C}_{10} \mathrm{H}_{9} \mathrm{Cl}_{2} \mathrm{O}_{3}\left[\mathrm{M}-\mathrm{NHCH}\left(\mathrm{CO}_{2} \mathrm{Et}\right)_{2}\right]^{+}$requires: 246.9928 .

Diethyl 5-chloro-6,8-dimethoxy-1-oxo-1,2-dihydroisoquinoline-3,3(4H)-dicarboxylate (24)

\section{Method A}

A solution containing $23(100 \mathrm{mg}, 0.26 \mathrm{mmol}), \mathrm{KI}$ (102 mg, $0.62 \mathrm{mmol}$ ) and $\mathrm{Cs}_{2} \mathrm{CO}_{3}(201 \mathrm{mg}, 0.62 \mathrm{mmol})$ in $\mathrm{CH}_{3} \mathrm{CN}(5 \mathrm{~mL})$ was stirred for $12 \mathrm{~h}$ at room temperature. The reaction was diluted with ethyl acetate $(20 \mathrm{~mL})$, washed with water $(20 \mathrm{~mL})$ and brine $(20 \mathrm{~mL})$. The organic phase was dried with anhydrous $\mathrm{Na}_{2} \mathrm{SO}_{4}$ and concentrated. The solid was purified by flash chromatography, on silica gel, with ethyl acetate/hexane (9:1) as the eluent; the cyclized product 24 (11 mg, $0.03 \mathrm{mmol}, 11 \%$ yield) and iodinated precursor 25 ( $25 \mathrm{mg}, 0.05 \mathrm{mmol}, 19 \%$ yield) were obtained.

\section{Method B}

25 (200 mg, $0.5 \mathrm{mmol}), \mathrm{Cs}_{2} \mathrm{CO}_{3}$ (401 mg, $1.0 \mathrm{mmol}$ ) and $\mathrm{CH}_{3} \mathrm{CN}$ ( $5 \mathrm{~mL}$ ) were added to an Ace sealed tube. The 
tube was irradiated at $200 \mathrm{~W}$, with maximum temperature of $130{ }^{\circ} \mathrm{C}$ for $10 \mathrm{~min}$. Then, the reaction was diluted in ethyl acetate $(20 \mathrm{~mL})$, washed with water $(20 \mathrm{~mL})$ and brine $(20 \mathrm{~mL})$. The organic phase was dried with anhydrous $\mathrm{Na}_{2} \mathrm{SO}_{4}$ and concentrated under reduced pressure affording the cyclized product $\mathbf{2 4}$ (150 $\mathrm{mg}, 0.39 \mathrm{mmol}, 77 \%$ yield).<smiles>CCOC(=O)C1(C(=O)OCC)Cc2c(Cl)c(OC)cc(OC)c2C(=O)N1</smiles>

mp 188.9-194.4 ${ }^{\circ} \mathrm{C}$; ${ }^{1} \mathrm{H}$ NMR $(500 \mathrm{MHz}$, $\left.\mathrm{CDCl}_{3}\right) \delta 1.25(\mathrm{t}, 6 \mathrm{H}$, $J 7.0 \mathrm{~Hz}, \mathrm{CO}_{2} \mathrm{CH}_{2} \mathrm{CH}_{3}$ ), $3.61\left(\mathrm{~s}, 2 \mathrm{H}, \mathrm{Ar}-\mathrm{CH}_{2}\right), 3.95$ (s, 3H, $\left.\mathrm{Ar}-\mathrm{OCH}_{3}\right), 3.97$ (s, $\left.3 \mathrm{H}, \mathrm{Ar}-\mathrm{OCH}_{3}\right), 4.19-4.27$ (m, 4H, $\mathrm{CO}_{2} \mathrm{CH}_{2} \mathrm{CH}_{3}$ ), 6.48 (s, $1 \mathrm{H}, \mathrm{Ar}-H), 6.58(\mathrm{~s}, 1 \mathrm{H}, \mathrm{NH}) ;{ }^{13} \mathrm{C} \mathrm{NMR}\left(126 \mathrm{MHz}, \mathrm{CDCl}_{3}\right)$ $\delta 13.9$ (2C), 32.3, 56.2, 56.5, 63.0 (2C), 64.1, 76.8, 77.3, 95.8, 109.7, 112.8, 136.7, 158.9, 160.7, 162.6, 167.3 (2C); LRMS (ESI) $m / z 388.1(30), 386.1\left([\mathrm{M}+\mathrm{H}]^{+}, 100\right)$; HRMS (TOF) $\mathrm{m} / z$, observed: $408.0823 ; \mathrm{C}_{17} \mathrm{H}_{20} \mathrm{ClNO}_{7} \mathrm{Na}[\mathrm{M}+\mathrm{Na}]^{+}$ requires: 408.0826 .

Methyl 3-chloro-2-(chloromethyl)-4,6-dimethoxybenzoate (27)<smiles>COC(=O)c1c(OC)cc(OC)c(Cl)c1CCl</smiles>

A solution containing acid 22 (200 mg, $0.87 \mathrm{mmol}$ ), $\mathrm{CH}_{3} \mathrm{I}$ $(82 \mu \mathrm{L}, 1.31 \mathrm{mmol})$ and $\mathrm{Cs}_{2} \mathrm{CO}_{3}$ (339 mg, $1.04 \mathrm{mmol}$ ) in DMF $(2.5 \mathrm{~mL})$ was stirred for $30 \mathrm{~min}$ at $\mathrm{rt}$. The reaction was diluted

in DCM $(15 \mathrm{~mL})$ and extracted with saturated aqueous $\mathrm{NaHCO}_{3}$ solution $(20 \mathrm{~mL})$ and brine $(20 \mathrm{~mL})$. The organic phase was dried with anhydrous $\mathrm{Na}_{2} \mathrm{SO}_{4}$ and concentrated under reduced pressure. The crude solid was purified by flash chromatography on silica gel with ethyl acetate/ hexane (2:1 to 1:1) as the eluent, providing a solid (141 mg, $0.51 \mathrm{mmol}, 59 \%$ yield). ${ }^{1} \mathrm{H}$ NMR ( $\left.500 \mathrm{MHz}, \mathrm{CDCl}_{3}\right) \delta 3.88$ (s, 3H, Ar- $\mathrm{CO}_{2} \mathrm{CH}_{3}$ ), 3.95 (s, 6H, $\mathrm{Ar}-\mathrm{OCH}_{3}$ ), 4.75 (s, 2H, Ar- $\mathrm{CH}_{2}-\mathrm{Cl}$ ), 6.53 (s, $1 \mathrm{H}, \mathrm{Ar}-\mathrm{H}$ ); LRMS (ESI) $\mathrm{m} / z 281.0$ (70), $279.0\left([\mathrm{M}+\mathrm{H}]^{+}, 100\right)$; HRMS (TOF) $\mathrm{m} / z$, observed: 301.0009; $\mathrm{C}_{11} \mathrm{H}_{12} \mathrm{Cl}_{2} \mathrm{O}_{4} \mathrm{Na}[\mathrm{M}+\mathrm{Na}]^{+}$requires: 301.0010 .

Diethyl 2-acetamido-2-(2-chloro-3,5-dimethoxy-6-(methoxycarbonyl)benzyl)malonate (29)<smiles>CCOC(=O)C(Cc1c(Cl)c(OC)cc(OC)c1OCC)(NC(C)=O)C(=O)OCC</smiles>

A solution of methyl 3-chloro-6-(chloromethyl)2,4-dimethoxybenzoate (115 mg, $0.47 \mathrm{mmol}, 27$ ), diethyl acetamidomalonate (102 mg, $0.47 \mathrm{mmol}, 28$ ), $\mathrm{Cs}_{2} \mathrm{CO}_{3}(368 \mathrm{mg}, 1.13 \mathrm{mmol})$ and $\mathrm{KI}(187 \mathrm{mg}, 1.13 \mathrm{mmol})$ in acetonitrile $(5 \mathrm{~mL})$ was stirred for 3 days at rt. The reaction was diluted with ethyl acetate $(40 \mathrm{~mL})$ and washed with water $(10 \mathrm{~mL})$ and brine $(10 \mathrm{~mL})$. The organic phase was dried with anhydrous $\mathrm{Na}_{2} \mathrm{SO}_{4}$ and concentrated under reduced pressure. The crude solid was purified by flash chromatography on silica gel, using ethyl acetate/hexane (4:1 to 1:1) as the eluent, giving a white solid (134.0 mg, $60 \%$ yield). mp 169.6-173.0 ${ }^{\circ} \mathrm{C}$; ${ }^{1} \mathrm{H}$ NMR $\left(500 \mathrm{MHz}, \mathrm{CDCl}_{3}\right) \delta 1.24(\mathrm{t}, 6 \mathrm{H}, J 7.1 \mathrm{~Hz}$, $\mathrm{CO}_{2} \mathrm{CH}_{2} \mathrm{CH}_{3}$ ), 1.99 (s, 3H, NHAc), 3.83 (s, 3H, $\mathrm{Ar}-\mathrm{OCH}_{3}$ ),

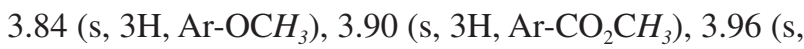
$\left.2 \mathrm{H}, \mathrm{Ar}-\mathrm{CH}_{2}-\mathrm{C}\right), 4.15$ (dq, $2 \mathrm{H}, \mathrm{J} 10.8,7.2 \mathrm{~Hz}, \mathrm{CO}_{2} \mathrm{CH}_{2} \mathrm{CH}_{3}$ ), 4.26 (dq, $\left.2 \mathrm{H}, J 10.8,7.2 \mathrm{~Hz}, \mathrm{CO}_{2} \mathrm{CH}_{2} \mathrm{CH}_{3}\right), 6.44(\mathrm{~s}, 1 \mathrm{H}$, NHAc), 6.47 (s, 1H, Ar- $H$ ); LRMS (EI) $m / z 424\left(\mathrm{M}^{+}-\mathrm{Cl}^{\text {, }}\right.$ 50), 314 (37), 312 (100), 244 (19), 238 (25); HRMS (TOF) $m / z$, observed: $482.1179 ; \mathrm{C}_{20} \mathrm{H}_{26} \mathrm{ClNO}_{9} \mathrm{Na}[\mathrm{M}+\mathrm{Na}]^{+}$ requires: 482.1193.

2-Acetamido-3-(2-chloro-3,5-dimethoxy-6-(methoxycarbonyl)phenyl)propanoic acid (30)<smiles>CCC(Cc1c(Cl)c(OC)cc(OC)c1C(=O)OC)C(=O)O</smiles>

To a solution of the diester $29(51 \mathrm{mg}, 0.1 \mathrm{mmol})$ in acetic acid $(2 \mathrm{~mL}), 6 \mathrm{~mol} \mathrm{~L}^{-1} \mathrm{HCl}$ solution $(2 \mathrm{~mL})$ was added. The flask was irradiated with $150 \mathrm{~W}$ at $90{ }^{\circ} \mathrm{C}$ for $10 \mathrm{~min}$. The crude mixture was concentrated under reduced pressure and purified by flash chromatography on silica gel, using DCM/MeOH (9:1 to 4:1) as the eluent, providing a solid (41 $\mathrm{mg}, 10.7 \mathrm{mmol}$, quantitative). ${ }^{1} \mathrm{H}$ NMR $\left(500 \mathrm{MHz}, \mathrm{DMSO}-d_{6}\right) \delta 1.68$ (s, 3H, NHAc), 3.30 (d, $\left.1 \mathrm{H}, J 3.2 \mathrm{~Hz}, \mathrm{Ar}-\mathrm{CH}_{2} \mathrm{CH}\right), 3.32$ (d, $1 \mathrm{H}, J 3.4 \mathrm{~Hz}, \mathrm{Ar}-$ $\mathrm{CH}_{2} \mathrm{CH}$ ), 3.80 (s, $6 \mathrm{H}, \mathrm{Ar}-\mathrm{OCH} \mathrm{H}_{3}$ ), 3.89 (s, $3 \mathrm{H}, \mathrm{Ar}-\mathrm{CO}_{2} \mathrm{CH}_{3}$ ), 4.35-4.42 (m, $\left.1 \mathrm{H}, \mathrm{Ar}-\mathrm{CH}_{2} \mathrm{CH}\right), 6.71$ (s, $\left.1 \mathrm{H}, \mathrm{Ar}-\mathrm{H}\right), 7.22$ (br $\mathrm{s}, 1 \mathrm{H}, \mathrm{N} H \mathrm{Ac}$ ), 8.33 (s, $1 \mathrm{H}, \mathrm{CO}_{2} H$ ) ; LRMS (ESI) $\mathrm{m} / z 362.0$ (20), $360.1\left([\mathrm{M}+\mathrm{H}]^{+}, 100\right)$; HRMS (TOF) $m / z$, observed: 382.0661; $\mathrm{C}_{15} \mathrm{H}_{18} \mathrm{ClNO}_{7} \mathrm{Na}[\mathrm{M}]^{+}$requires: 382.0669 .<smiles>COc1cc(CCl)c(C#N)c(OC)c1</smiles>

2-(Chloromethyl)-4,6-dimethoxybenzonitrile (31)

A solution containing 2-(chloromethyl)-4,6-dimethoxybenzaldehyde (107.6 mg, $0.5 \mathrm{mmol}$, 9) and $\mathrm{NaN}_{3}(33 \mathrm{mg}, 0.5 \mathrm{mmol})$ in $\mathrm{POCl}_{3}(233 \mu \mathrm{L}, 2.5 \mathrm{mmol})$ was stirred overnight at $50^{\circ} \mathrm{C}$ in $\mathrm{N}_{2}$. The mixture was concentrated under reduced pressure and the crude product was purified by flash chromatography on silica gel, using ethyl acetate/ hexane (2:1) as the eluent, providing a red solid $(65 \mathrm{mg}$, $0.31 \mathrm{mmol}, 62 \%$ yield). $\mathrm{mp} 112.4-114.0{ }^{\circ} \mathrm{C} ;{ }^{1} \mathrm{H}$ NMR $\left(500 \mathrm{MHz}, \mathrm{CDCl}_{3}\right) \delta 3.89\left(\mathrm{~s}, 3 \mathrm{H}, \mathrm{Ar}-\mathrm{OCH}_{3}\right), 3.92(\mathrm{~s}, 3 \mathrm{H}$, Ar- $\left.\mathrm{OCH}_{3}\right), 4.68$ (s, $\left.2 \mathrm{H}, \mathrm{Ar}-\mathrm{CH}_{2}\right), 6.43(\mathrm{~d}, 1 \mathrm{H}, J 2.2 \mathrm{~Hz}$, Ar- $H$ ), 6.67 (d, $1 \mathrm{H}, J 2.2 \mathrm{~Hz}, \mathrm{Ar}-H) ;{ }^{13} \mathrm{C}$ NMR $(126 \mathrm{MHz}$, 
$\left.\mathrm{CDCl}_{3}\right) \delta 43.4,55.8,56.2,94.0,98.2,106.7,110.0,114.8$, 143.7, 163.3, 164.3; LRMS (EI) $m / z 213$ (32), $211\left(\mathbf{M}^{+}, 100\right)$, 176 (72), 146 (20); HRMS (TOF) $m / z$, observed: 234.0273; $\mathrm{C}_{10} \mathrm{H}_{10} \mathrm{ClNO}_{2} \mathrm{Na}[\mathrm{M}+\mathrm{Na}]^{+}$requires: 234.0297.

Diethyl 2-acetamido-2-(2-cyano-3,5-dimethoxybenzyl) malonate (32)<smiles>CCOC(=O)C(Cc1cc(OC)cc(OC)c1C#N)(NC(C)=O)C(=O)OCC</smiles>

A solution of methyl 2 - ( c h 1 o r o m e th y 1 ) 4,6-dimethoxybenzonitrile (384.5 mg, $1.8 \mathrm{mmol}, 31$ ), diethyl acetamidemalonate (475 mg, $2.19 \mathrm{mmol}, \mathbf{2 8}$ ), $\mathrm{Cs}_{2} \mathrm{CO}_{3}(712 \mathrm{mg}, 2.19 \mathrm{mmol}$ ) and $\mathrm{KI}$ (364 mg, $2.19 \mathrm{mmol}$ ) in acetonitrile $(7 \mathrm{~mL})$ was stirred for overnight at $\mathrm{rt}$. The mixture was diluted with ethyl acetate $(15 \mathrm{~mL})$ and quenched with water $(10 \mathrm{~mL})$ and $\mathrm{Na}_{2} \mathrm{SO}_{3}$. The organic phase was separated, extracted with aqueous $2 \mathrm{M}$ hydrochloridric acid solution $(7 \mathrm{~mL})$ and brine $(10 \mathrm{~mL})$. The organic phase was dried with anhydrous $\mathrm{Na}_{2} \mathrm{SO}_{4}$ and concentrated under reduced pressure. The crude solid was purified by flash chromatography on silica gel, using ethyl acetate/hexane $(1: 1)$ as the eluent, giving a white solid (548.5 mg, $1.4 \mathrm{mmol}, 78 \%$ yield). mp 168.0-171.9 ${ }^{\circ} \mathrm{C}$; ${ }^{1} \mathrm{H}$ NMR $\left(500 \mathrm{MHz}, \mathrm{CDCl}_{3}\right) \delta 1.29(\mathrm{t}, 6 \mathrm{H}, J 7.1 \mathrm{~Hz}$, $\mathrm{CO}_{2} \mathrm{CH}_{2} \mathrm{CH}_{3}$ ), 2.05 (s, $\left.3 \mathrm{H}, \mathrm{NH} A c\right), 3.79$ (s, $2 \mathrm{H}, \mathrm{Ar}-\mathrm{CH}_{2}$ ), 3.80 (s, $\left.3 \mathrm{H}, \mathrm{Ar}-\mathrm{OCH}_{3}\right), 3.87$ (s, $3 \mathrm{H}, \mathrm{OCH}_{3}$ ), 4.23-4.37 $\left(\mathrm{m}, 4 \mathrm{H}, \mathrm{CO}_{2} \mathrm{CH}_{2} \mathrm{CH}_{3}\right), 6.28(\mathrm{~d}, 1 \mathrm{H}, J 2.2 \mathrm{~Hz}, \mathrm{Ar}-\mathrm{H}), 6.36$ (d, $1 \mathrm{H}, J 2.2 \mathrm{~Hz}, \mathrm{Ar}-H$ ), 6.59 (s, $1 \mathrm{H}, \mathrm{NHAc}$ ); ${ }^{13} \mathrm{C}$ NMR $\left(126 \mathrm{MHz}, \mathrm{CDCl}_{3}\right) \delta 13.9$ (2C), 23.1, 36.6, 55.6, 56.0, 63.0 (2C), 66.3, 76.8, 77.0, 77.3, 95.8, 97.0, 108.7, 115.5, 142.2, 163.3, 163.6, 167.3 (2C), 169.4; LRMS (ESI) $\mathrm{m} / \mathrm{z}$ $393.1\left(\mathrm{M}^{+}, 100\right)$; HRMS (TOF) $\mathrm{m} / z$, observed: 415.1453; $\mathrm{C}_{19} \mathrm{H}_{24} \mathrm{~N}_{2} \mathrm{O}_{7} \mathrm{Na}[\mathrm{M}+\mathrm{Na}]^{+}$requires: 415.1481 .

Sodium 2-acetamido-2-(2-cyano-3,5-dimethoxybenzyl) malonate (33)<smiles>COc1cc(CC(NC(N)=O)(C(N)=O)C(=O)O[Na])c(C#N)c(OC)c1</smiles>

A mixture containing nitrile 32 (100 mg, $0.26 \mathrm{mmol})$ and $2 \mathrm{M} \mathrm{NaOH}$ solution $(10 \mathrm{~mL})$ was placed in an ultrasonic bath at $80{ }^{\circ} \mathrm{C}$ for $45 \mathrm{~min}$, under $\mathrm{N}_{2}$ atmosphere. The reaction was then treated with $2 \mathrm{M} \mathrm{HCl}$ solution at $\mathrm{pH} 2$ and frozen for 2 days. After thawing, the precipitate was filtered by vacuum and water phase was removed in high vacuum affording a white solid, the disodium salt $\mathbf{3 3}$ (43 mg, 0.14 mmol, 54\% yield). mp 157.9-187.1 ${ }^{\circ} \mathrm{C}$; ${ }^{1} \mathrm{H}$ NMR $\left(500 \mathrm{MHz}, \mathrm{DMSO}-d_{6}\right) \delta 1.92(\mathrm{~s}, 3 \mathrm{H}, \mathrm{NH} A c), 3.51(\mathrm{~s}, 2 \mathrm{H}$, $\left.\mathrm{Ar}-\mathrm{CH}_{2}\right), 3.82$ (s, $3 \mathrm{H}, \mathrm{Ar}-\mathrm{OCH}_{3}$ ), 3.87 (s, $3 \mathrm{H}, \mathrm{Ar}-\mathrm{OCH}_{3}$ ), $6.38(\mathrm{~d}, 1 \mathrm{H}, J 2.2 \mathrm{~Hz}, \mathrm{Ar}-H), 6.62$ (d, 1H, J $2.0 \mathrm{~Hz}, \mathrm{Ar}-$
$H$ ), 7.91 (s, $1 \mathrm{H}, \mathrm{NHAc}) ;{ }^{13} \mathrm{C}$ NMR (126 MHz, DMSO- $d_{6}$ ) $\delta$ 22.4, 36.1, 39.0, 39.2, 39.3, 39.7, 39.8, 40.0, 55.6, 55.8, 56.3, 66.4, 95.1, 97.2, 108.2, 115.3, 142.7, 162.9, 163.3, 168.5 (2C), 169.3; LRMS (ESI) $\mathrm{m} / z 383.1[\mathrm{M}+2 \mathrm{H}]^{+}, 40$ ), $\left.337.1[\mathrm{M}-2 \mathrm{Na}]^{+}, 100\right), 117.1$ (22).

2-Acetamido-3-(2-cyano-3,5-dimethoxyphenyl)propanoic acid (34)<smiles>COc1cc(CC(NC(C)=O)C(=O)O)c(C#N)c(OC)c1</smiles>

To a solution of nitrile $\mathbf{3 2}$ (82 $\mathrm{mg}, 0.21 \mathrm{mmol})$ in ethanol ( $2 \mathrm{~mL}) 35 \% \mathrm{KOH}$ solution $(2 \mathrm{~mL})$ was added and the mixture was stirred for $2.5 \mathrm{~h}$ at $80{ }^{\circ} \mathrm{C}$. Then the reaction was diluted in water $(15 \mathrm{~mL})$ and extracted with diethyl ether $(2 \times 20 \mathrm{~mL})$. The aqueous phase was acidified with $2 \mathrm{M} \mathrm{HCl}$ solution until pH 2 and extracted with DCM $(3 \times 15 \mathrm{~mL})$. The organic phase was washed with water, dried with anhydrous $\mathrm{Na}_{2} \mathrm{SO}_{4}$ and concentrated under reduced pressure, providing a white solid, the acid 34 ( $28 \mathrm{mg}, 0.095 \mathrm{mmol}, 45 \%$ yield); without further purification. ${ }^{1} \mathrm{H}$ NMR $\left(500 \mathrm{MHz}, \mathrm{DMSO}-d_{6}\right) \delta 1.77$ (s, 3H, $\mathrm{NHAc}$ ), 2.93 (dd, $1 \mathrm{H}, J$ 14.0, $9.9 \mathrm{~Hz}, \mathrm{Ar}_{-} \mathrm{CH}_{2} \mathrm{CH}$ ), $3.18\left(\mathrm{dd}, 1 \mathrm{H}, J 14.0,5.1 \mathrm{~Hz}, \mathrm{Ar}-\mathrm{CH}_{2} \mathrm{CH}\right), 3.83$ (s, 3H, $\left.\mathrm{Ar}-\mathrm{OCH}_{3}\right), 3.88\left(\mathrm{~s}, 3 \mathrm{H}, \mathrm{Ar}-\mathrm{OCH}_{3}\right), 4.51(\mathrm{dt}, 1 \mathrm{H}, J 4.9$, $\left.3.3 \mathrm{~Hz}, \mathrm{Ar}-\mathrm{CH}_{2} \mathrm{CH}\right) 6.60$ (d, $\left.1 \mathrm{H}, J 2.2 \mathrm{~Hz}, \mathrm{Ar}-H\right), 6.61$ (d, $1 \mathrm{H}, J 2.2 \mathrm{~Hz}, \mathrm{Ar}-H), 8.27$ (d, 1H, J 8.4 Hz, NHAc), 12.81 (br s, $\left.1 \mathrm{H}, \mathrm{CO}_{2} H\right) ;{ }^{13} \mathrm{C}$ NMR $\left(126 \mathrm{MHz}\right.$, DMSO- $\left.d_{6}\right) \delta 22.3,35.5$, 51.9, 55.8, 56.3, 93.3, 96.9, 108.2, 115.6, 144.2, 162.9, 163.7, 169.2, 172.6; LRMS (ESI) $\mathrm{m} / 2.293 .1\left(\mathrm{M}^{+}, 100\right)$; HRMS (TOF) $m / z$, observed: 315.0944; $\mathrm{C}_{14} \mathrm{H}_{16} \mathrm{~N}_{2} \mathrm{O}_{5} \mathrm{Na}$ $[\mathrm{M}+\mathrm{Na}]^{+}$requires: 315.0956 .

1-Imino-6,8-dimethoxy-1,2,3,4-tetrahydroisoquinoline3-carboxylic acid (35)<smiles>COc1cc2c(c(OC)c1)C(=N)NC(C(=O)O)C2</smiles>

A solution of nitrile $\mathbf{3 2}$ (82 $\mathrm{mg}, 0.2 \mathrm{mmol}$ ) in $2 \mathrm{M}$ $\mathrm{HCl}(1 \mathrm{~mL})$ and dioxane $(1.2 \mathrm{~mL})$ was refluxed (at $115^{\circ} \mathrm{C}$ ) for $48 \mathrm{~h}$ under $\mathrm{N}_{2}$ atmosphere. The solvent was removed under reduced pressure and the residue was lyophilized, furnishing $72 \mathrm{mg}$ of brown solid. The crude product was purified by semi preparative HPLC using a C18 column, providing a white solid 35 (6 mg, $0.024 \mathrm{mmol}, 12 \%$ yield). ${ }^{1} \mathrm{H}$ NMR $\left(500 \mathrm{MHz}, \mathrm{DMSO}-d_{6}\right) \delta 3.20\left(\mathrm{~m}, 1 \mathrm{H}, \mathrm{Ar}-\mathrm{CH}_{2} \mathrm{CH}\right.$ ), 3.29 (m $1 \mathrm{H}, \mathrm{Ar}-\mathrm{CH}_{2} \mathrm{CH}$ ), 3.88 (s, 3H, Ar- $\mathrm{OCH}_{3}$ ), 3.95 (s, 3H, $\left.\mathrm{Ar}-\mathrm{OCH}_{3}\right), 4.48$ (td, $\left.1 \mathrm{H}, J 6.4,3.6 \mathrm{~Hz}, \mathrm{Ar}_{-} \mathrm{CH}_{2} \mathrm{CH}\right), 6.68$ (d, $1 \mathrm{H}, J 2.3 \mathrm{~Hz}, \mathrm{Ar}-H), 6.74$ (d, $1 \mathrm{H}, J 2.3 \mathrm{~Hz}, \mathrm{Ar}-H), 8.71$ $(\mathrm{s}, 1 \mathrm{H}, \mathrm{C}=\mathrm{N} H), 8.81\left(\mathrm{~s}, 1 \mathrm{H}, \mathrm{CO}_{2} H\right), 8.94(\mathrm{~d}, 1 \mathrm{H}, J 3.3 \mathrm{~Hz}$, CHN $H$ ); ${ }^{13} \mathrm{C}$ NMR (126 MHz, DMSO- $d_{6}$ ) $\delta 35.8,44.2$, 44.4, 44.5, 44.7, 44.9, 45.1, 45.2, 55.9, 61.3, 61.8, 103.1, 
106.9, 112.1, 146.1, 163.3, 166.5, 170.5, 176.5; LRMS (ESI) $\mathrm{m} / z 252.1$ (15), $251.1\left(\mathrm{M}^{+}, 100\right), 207.1$ (16), 169.1 (55); HRMS (TOF) $m / z$, observed: $249.0867 ; \mathrm{C}_{12} \mathrm{H}_{13} \mathrm{~N}_{2} \mathrm{O}_{4}$ $[\mathrm{M}-\mathrm{H}]^{-}$requires: 249.0875 .

\section{Supplementary Information}

Supplementary data $\left({ }^{1} \mathrm{H}\right.$ and ${ }^{13} \mathrm{C}$ NMR spectra) are available free of charge at http://jbcs.sbq.org.br as PDF file.

\section{Acknowledgments}

We express our gratitude to FAPESP (grant No. 2014/25659-8) for financial support. Oliveira Filho thanks UFABC for the fellowship. We also would like to thank Prof Dr Rodrigo Luiz Oliveira Rodrigues Cunha for providing compound $\mathbf{2 8}$.

\section{References}

1. Chua, C.-B.; Sun, C.-K.; Tsui, H.-W.; Yang, P.-J.; Lee, K.-H.; Hsu, C.-W.; Tsai, I-T.; Clin. Toxicol. 2017, 55, 624.

2. Oliveira, E. S. M.; Aguiar, A. S.; J. Bras. Nefrol. 2015, 37, 241.

3. Cairasco-Garcia, N.; Moyses-Neto, M.; Del Vecchio, F.; Oliveira, J. A.; dos Santos, F. L.; Castro, O. W.; Arisi, G. M.; Dantas, M.; Carolino, R. O.; Coutinho-Netto, J.; Dagostin, A. L.; Rodrigues, M. C.; Leão, R. M.; Quintiliano, S. A.; Silva Jr., L. F.; Gobbo-Neto, L.; Lopes, N. P.; Angew. Chem., Int. Ed. 2013, 52, 13067.

4. Quintiliano, S. A. P.; Silva Jr., L. F.; Tetrahedron Lett. 2012, 53, 3808 .

5. Pichierri, F.; J. Mol. Struct. 2015, 1079, 274.

6. Quintiliano, S. A. P.; Reação de Álcoois Homoalílicos com Tálio(III), Iodo e Iodo Hipervalente, Dicloração de Cetonas e Estudos Visando à Síntese Total da Caramboxina; $\mathrm{PhD}$ Thesis, Universidade de São Paulo: São Paulo, Brazil, 2010. DOI: 10.11606/T.46.2010.tde-27042010-082909.

7. Ledford, N. D.; Gibbs, P. C.; Wood Jr., H. B.; Barfield, M.; Org. Prep. Proced. Int. 1986, 18, 263.

8. In, J.; Hwang, S.; Kim, C.; Seo, J. H.; Kim, S.; Eur. J. Org. Chem. 2013, 965.

9. Judd, K. E.; Mahon, M. F.; Caggiano, L.; Synthesis 2009, 16, 2809.

10. Lebel, H.; Leogane, O.; Org. Lett. 2005, 7, 4107; Leogane, O.; Lebel, H.; Synthesis 2009, 11, 1935.

11. Garbaccio, R. M.; Stachel, S. J.; Baeschlin, D. K.; Danishefsky, S. J.; J. Am. Chem. Soc. 2001, 123, 10903.

12. Nawrat, C. C.; Palmer, L. I.; Blake, A. J.; Moody, C. J.; J. Org. Chem. 2013, 78, 5587.

13. Young, D. D.; Torres-Kolbus, J.; Deiters, A.; Bioorg. Med. Chem. Lett. 2008, 18, 5478.
14. Banwell, M. G.; Bissett, B. D.; Busato, S.; Cowden, C. J.; Hockless, D. C. R.; Holman, J. W.; Read, R. W.; Wu, A. W.; J. Chem. Soc., Chem. Commun. 1995, 2551.

15. Spyropoulos, C.; Kokotos, C. G.; J. Org. Chem. 2014, 79, 4477.

16. Jubilut, G. N.; Cilli, E. M.; Tominaga, M.; Miranda, A.; Okada, Y.; Nakaie, C. R.; Chem. Pharm. Bull. 2001, 49, 1089.

17. In, J.; Hwang, S.; Kim, C.; Seo, J. H.; Kim, S.; Eur. J. Org. Chem. 2013, 965.

18. Knölker, H.-J.; Braxmeier, T.; Synlett 1997, 925.

19. Travis, B. R.; Sivakumar, M.; Hollist, G. O.; Borhan, B.; Org. Lett. 2003, 5, 1031.

20. Chakraborty, D.; Gowda, R. R.; Malik, P.; Tetrahedron Lett. 2009, 50, 6553.

21. Abiko, A.; Roberts, J. C.; Takemasa, T.; Masamune, S.; Tetrahedron Lett. 1986, 27, 4537.

22. Kurti, L.; Czako, B.; Strategic Applications of Named Reactions in Organic Synthesis, $1^{\text {st }}$ ed.; Elsevier: London, UK, 2005, p. 355.

23. Montanari, F.; J. Org. Chem. 1986, 51, 569.

24. Couladouros, E. A.; Mihou, A. P.; Bouzas, E. A.; Org. Lett. 2004, 6, 977.

25. Kaiser, C. R.; Quim. Nova 2000, 23, 231.

26. Valdomir, G.; Padrón, J. I.; Padrón, J. M.; Martín, V. S.; Davyt, D.; Synthesis 2014, 46, 2451.

27. Escudero, M. I.; Kremenchuzky, L. D.; Perillo, I. A.; Cerecetto, H.; Blanco, M. M.; Synthesis 2011, 4, 571.

28. Humphrey, C. E.; Furegati, M.; Laumen, K.; Vecchia, L. L.; Leutert, T.; Müller-Hartwieg, J. C. D.; Vögtle, M.; Org. Process Res. Dev. 2007, 11, 1069.

29. Sribalan, R.; Sangili, A.; Banuppriya, G.; Padmini, V.; New J. Chem. 2017, 41, 3414.

30. Lignier, P.; Estager, J.; Kardos, N.; Gravouil, L.; Gazza, J.; Naffrechoux, E.; Draye, M.; Ultrason. Sonochem. 2011, 18, 28.

31. Loreau, O.; Georgin, D.; Taran, F.; Audisio, D.; J. Labelled Compd. Radiopharm. 2015, 58, 425.

32. Beaton, H.; Hamley, P.; Tinker, A. C.; Tetrahedron Lett. 1998, 39, 1227.

33. Pincock, J. A.; Wedge, P. J.; J. Org. Chem. 1994, 59, 5587.

34. Snyder, S. A.; Zografos, A. L.; Lin, Y.; Angew. Chem., Int. Ed. 2007, 46, 8186.

35. Kim, B.-T.; Kim, H.-S.; Moon, W. S.; Hwang, K.; Tetrahedron 2009, 65, 4625.

36. Proisy, N.; Sharp, S. Y.; Boxall, K.; Connelly, S.; Roe, S. M.; Prodromou, C.; Slawin, A. M.; Pearl, L. H.; Workman, P.; Moody, C. J.; Chem. Biol. 2006, 13, 1203.

Submitted: June 13, 2018

Published online: October 9, 2018 